\title{
A Job Is Not a Hobby: The Judicial Revival of Corporate Paternalism and Its Problematic Implications
}

\section{Citation}

Leo E. Strine, Jr., A Job Is Not a Hobby: The Judicial Revival of Corporate Paternalism and Its Problematic Implications, (The Harvard John M. Olin Discussion Paper Series No. 804, Jan. 2015).

\section{Published Version}

http://www.law.harvard.edu/programs/olin_center/papers//pdf/Strine_804.pdf

\section{Permanent link}

http://nrs.harvard.edu/urn-3:HUL.InstRepos:16162407

\section{Terms of Use}

This article was downloaded from Harvard University's DASH repository, and is made available under the terms and conditions applicable to Other Posted Material, as set forth at http:// nrs.harvard.edu/urn-3:HUL.InstRepos:dash.current.terms-of-use\#LAA

\section{Share Your Story}

The Harvard community has made this article openly available.

Please share how this access benefits you. Submit a story.

\section{Accessibility}


ISSN 1936-5349 (print)

ISSN 1936-5357 (online)

\title{
HARVARD
}

JOHN M. OLIN CENTER FOR LAW, ECONOMICS, AND BUSINESS

\author{
A JOB IS NOT A HOBBY: \\ THE JUDICIAL REVIVAL OF CORPORATE PATERNALISM AND \\ ITS PROBLEMATIC IMPLICATIONS \\ Leo E. Strine, Jr.
}

Discussion Paper No. 804

$1 / 2015$

Harvard Law School

Cambridge, MA 02138

This paper can be downloaded without charge from:

The Harvard John M. Olin Discussion Paper Series: http://www.law.harvard.edu/programs/olin_center/

The Social Science Research Network Electronic Paper Collection:

$\underline{\text { http://ssrn.com/abstract=2555816 }}$

This paper is also a discussion paper of the Harvard Law School Program on Corporate Governance 


\title{
A Job Is Not a Hobby: The Judicial Revival of Corporate Paternalism and Its Problematic Implications
}

\author{
Leo E. Strine, Jr. ${ }^{* * *}$ \\ Chief Justice \\ Delaware Supreme Court
}

* Leo E. Strine, Jr. is Chief Justice of the Delaware Supreme Court; Austin Wakeman Scott Lecturer on Law and Senior Fellow, Program on Corporate Governance, Harvard Law School; Adjunct Professor of Law, University of Pennsylvania Law School and Vanderbilt University Law School; and Henry Crown Fellow, Aspen Institute.

${ }^{* *}$ The author is grateful for incisive thoughts from Jennifer Arlen, Margaret Blair, Bill Budinger, Patricia Enerio, Jeff Gordon, Joe Grundfest, Larry Hamermesh, Susan Hassan, Matthew Jennejohn, Eric Klinger-Wilensky, Jonathan Lipson, Marty Lipton, Jennifer Muller, Bob Mundheim, Donna Nagy, Chuck O’Kelley, Alan Palmiter, Kim Rucker, Faiza Saeed, Damon Silvers, Eric Talley, Randall Thomas, and Nicholas Walter. The author also appreciates the diligent labor of Andrew Berni, Elane Boulden, Dorothy Shapiro, and Sonia Steinway on this paper. The author also thanks the Securities Regulation Institute of Northwestern University School of Law and the American Constitution Society Student Chapter at Harvard Law School, both of which hosted lectures based on this article. 


\begin{abstract}
$\underline{\text { Abstract }}$
This article connects the Supreme Court's decision in Burwell v. Hobby Lobby to the history of "corporate paternalism." It details the history of employer efforts to restrict the freedom of employees, and legislative attempts to ensure worker freedom. It also highlights the role of employment in healthcare coverage, and situates the Affordable Care Act's "minimum essential guarantees" in a historical and global context. The article also discusses how Hobby Lobby combines with the Supreme Court's earlier decisions in Citizens United and National Federation of Independent Business v. Sebelius to constrain the government's ability to extend the social safety net, and shows how those decisions put pressure on corporate law itself.

The article was the subject of lectures to the Securities Regulation Institute of Northwestern University School of Law and the American Constitution Society Student Chapter at Harvard Law School.
\end{abstract}

Keywords: Hobby Lobby; corporate law; corporate paternalism 


\section{Introduction}

A job is not a hobby. That is the title of this article for more than one reason. The first, of course, is because this article addresses the Supreme Court's decision in Burwell v. Hobby Lobby. ${ }^{1}$ But more importantly, it reflects a fundamental truth for most workers in a capitalist economy. Few of us work solely because our jobs fulfill all of our emotional, aesthetic, spiritual, avocational, or hedonic needs. Most of us work because we need to feed, house, and otherwise provide for ourselves and our families.

Precisely because most of us must take jobs, we often spend a majority of our waking hours in a domain where the rules are set by others. What to wear, how much we can talk to our colleagues - much less reach out to family members - and what we can say, what we can use the computer to do, and even when we can use the bathroom are all influenced by employers. Of course, long before capitalism emerged, there were periods of human history - such as the feudal era - when workers faced even more invasive controls and there was really no limit to the employer's rule, at work or at home.

But what is often forgotten is that when the United States made the transition from subsistence farming to industrial capitalism, some feudal practices were revived. As most Americans stopped being small farmers and artisans, and began more and more to earn their keep as the employees of large business enterprises, a new strain of feudalism returned in the form of something that might charitably be called "corporate paternalism.” Motivated by many factors, employers not only controlled employee behavior during the work days - which were long - and the work week - ditto - but

${ }^{1}$ Burwell v. Hobby Lobby, 134 S. Ct. 2751 (2014) [hereinafter Hobby Lobby]. 
attempted to control what their workers did with their scarce free time and their scarce wages. Many of these motivations were explicitly phrased in religious or moral terms. For example, some employers paid their workers not in cash, but in scrip that could only be used in company stores, in part so that employees could not use their pay to buy liquor. Some employers conditioned employment or higher wages on employees following the employers' moral code, including church attendance on Sundays. The employees’ religious beliefs, or how they wanted to spend their own money, were subordinate.

Eventually, however, as more Americans had to work for others to support themselves, labor advocates argued that an employee's wage was his own, earned by his sweat, and the worker, not the employer, should be able to spend it in whatever lawful way he chose. Paying in scrip, tokens, "dope checks," or coupons was made illegal, first at the state, and then at the federal level, so that workers had to be paid regularly in unrestricted cash. At the same time, labor advocates promoted the idea that a job should come with a bottom-line guarantee of economic support, through protections such as a minimum wage, Social Security to address the needs of the disabled and the elderly, unemployment insurance and the like. These programs were deemed entitlements that automatically came with a job; that is, every worker was entitled to receive these benefits, regardless of a particular employer’s objections.

For example, when an employer refused to pay into Social Security on the grounds that doing so violated his Amish faith, the U.S. Supreme Court found that any burden on the employer was too slight to justify denying workers the economic protections deemed 
necessary by society. ${ }^{2}$ In another case, in which the Supreme Court determined that one employee's right to take off work on his Sabbath burdened other employees, the Court quoted Judge Learned Hand: “The First Amendment ... gives no one the right to insist that in pursuit of their own interests others must conform their conduct to his own religious necessities.”3

From at least the $19^{\text {th }}$ century, worker advocates have contended that access to adequate medical care is part of the minimum essential package necessary for human dignity and fulfillment. ${ }^{4}$ Although the U.S. stumbled in this direction far more slowly than other industrialized nations, ${ }^{5}$ the trajectory was clear. The Social Security system began in the 1930s as a way to alleviate poverty among the elderly. ${ }^{6}$ In 1965 , the program expanded to include health insurance coverage under Medicare, recognizing that the "full value of Social Security would not be realized unless provision[s] were made to deal with the problem of costs of illnesses among our older citizens,” in President Lyndon Johnson's words. $^{7}$ At the same time, the government established Medicaid to provide health coverage for some of those living in poverty, especially children. ${ }^{8}$

${ }^{2}$ See United States v. Lee, 455 U.S. 252 (1982).

${ }^{3}$ Estate of Thornton v. Caldor, Inc., 472 U.S. 703, 710 (1985) (quoting Otten v. Baltimore \& Ohio R. Co., 205 F.2d 58, 61 (2d Cir. 1953)).

${ }^{4}$ See David Orentlicher, Rights to Healthcare in the United States: Inherently Unstable, 38 Ам. J.L. \& MEDICINE 326, 327-28 (2012).

${ }^{5}$ Michael Nelson, Achtung! After 125 Years of Success, the German Health Care System Is in Code Blue, 44 InT’L LAW. 1045, 1047-48 (2010) (“Germany’s heath care system dates back to 1883 ....”).

${ }^{6}$ Social Security Act, 49 Stat. 620 (1935).

${ }^{7}$ Social Security History: Presidential Quotes, http://www.ssa.gov/history/lbjstate.html.

${ }^{8}$ Social Security Amendments of 1965, Pub. L. 89-97 (1965). 
Eventually, Medicaid coverage was extended to children above the poverty line, ${ }^{9}$ and drug coverage was added to Medicare. ${ }^{10}$ And with the Affordable Care Act (ACA), most American workers were for the first time provided with a guarantee that a job would come with access not just to a minimum cash wage, but also, to quote the statute, a “minimum essential” guarantee of "quality, affordable health care.”"11

But in Burwell v. Hobby Lobby, the U.S. Supreme Court determined that an employer could, for religious reasons, deny its employees the full range of medical options that the federal government set as the ACA's “minimum essential coverage."12 The Hobby Lobby majority made clear that at least for religious principles they appeared to be familiar with, they would consider any stated religious objection by an employer to be compelling. And seemingly no government interest could be sufficient to overcome that objection, because the government could simply require the rest of us to pay what the employer refused. Thus, rather than conceiving of the minimum essential health care coverage as the employee's, Hobby Lobby construed it as the employer's, with the employer having the right to decide for its employees what health care options it would cover. In other words, the worker's right - as a minimum benefit of employment in a secular society - to make choices about her own medical needs is trumped by the employer's right to ensure that any funds from its coffers are not used in ways that the employer finds religiously objectionable. As the Supreme Court noted in a 1943 case

\footnotetext{
${ }^{9}$ Balanced Budget Act of 1997, 111 Stat. 251.

${ }^{10}$ Medicare Prescription Drug, Improvement, and Modernization Act, 117 Stat. 2066 (2003).

1142 U.S.C. $\S \S 18001-18121$.

${ }^{12} I d$.
} 
involving religious liberty, part of its job is to "determine where the rights of one end and those of another begin" ${ }^{13}$ - and in Hobby Lobby, the Court determined that the rights of the employer extend beyond the workplace and into the worker's doctor's office.

This reasoning is difficult to confine. Hobby Lobby's only objection was that it did not want any of its money to fund four specific contraceptives that were required as part of the ACA's minimum essential coverage. Of course, the company itself did not have to pay for the contraceptives; instead, it was only required to fund an insurance pool that would cover those contraceptives if workers chose to use them. By that same reasoning, an employer could object to the myriad medical interventions that violate some religious faith - all contraceptives, blood transfusions, devices made with porcine or bovine collagen, and so on. And that same logic extends beyond health insurance: under Hobby Lobby, an employer could condition the payment of cash wages on an employee’s binding agreement not to spend them in ways that the employer finds religiously objectionable, including on liquor, hot beverages, tobacco, condoms, pork chops, or crab cakes, to name just a few examples of products that violate some religion's strictures.

This implication of Hobby Lobby is particularly worrisome because it coincides with an increase in other limits on the freedom of low-wage workers and disturbing growth in economic inequality. The decline of labor unions has weakened one potential counterweight to employer power. Employers are limiting the privacy of workers through technology - such as workplace phone and computer monitoring, cameras, or

${ }^{13}$ West Virginia State Bd. of Educ. v. Barnette, 319 U.S. 624, 630 (1943). 
drug and nicotine testing - for bottom line, business reasons. With recent structural changes in the labor market, Americans are also less able to find new employment that allows them to maintain a middle-class standard of living, and therefore more likely to keep the jobs they have. Worries about workers being able to support their own families are most acute when discussing contraceptive use, which was at issue in Hobby Lobby. Controlling family size is often critical to providing opportunities for the existing children of families who, like most of us, do not have the time or the means to care for, much less pay the college tuition for, more than one or two children. Access to contraception was set as part of the minimum essential guarantee under the Affordable Care Act, a right guaranteed to all workers as a function of their employment. In holding that an employer's religious objection can override the essential rights of its employees, the decision represents a judicial revival of corporate paternalism, potentially subjecting millions of American workers to restrictions that had seemingly been eliminated long ago by our elected representatives.

Combined with other recent Supreme Court decisions, including Citizens United $^{14}$ and the part of the National Federation of Independent Business v. Sebelius ${ }^{15}$ decision that inhibited the expansion of Medicaid, Hobby Lobby acts as a constraint on the government's ability to extend the social safety net at the same time that substantial economic inequality is increasing and the middle class is eroding. Given the identity of the Justices in the majority in each of these cases, it is likely not coincidental that the

\footnotetext{
${ }^{14}$ Citizens United v. FEC, 558 U.S. 310 (2010).

${ }^{15}$ Nat'l Fed'n of Indep. Bus. v. Sebelius, 132 S. Ct. 2566 (2012).
} 
combined force of these decisions is to make it more difficult for Congress to expand the social safety net. Along with Citizens United, Hobby Lobby has the potential, in the name of protecting the rights of the elite few wielding corporate power, to limit the freedom of and put at greater risk the many more Americans who work for corporations and whose lives are influenced by corporate conduct.

Hobby Lobby also combines with Citizens United to put pressure on corporate law. Under existing corporate law, at least in Delaware, the duty of the board of directors is to maximize profit for stockholders, within the constraints on their discretion set by external law and regulations. Corporate managers can make decisions on behalf of the corporation that benefit other constituents, but only if they also have the purpose of promoting stockholder welfare. The U.S. Supreme Court rarely addresses corporate issues, which are traditionally the province of state law, and its holdings in both Citizens United and Hobby Lobby seem to misunderstand what corporate law means, and thus threaten to disrupt how it operates. How can a for-profit entity without a religious purpose clause in its charter have a religious identity, given that much of the reason for a corporation is to create a distinct legal entity that shields its equity owners from the corporation's liabilities? And if so, how? Can a corporation have its identity conflated with its managers or its stockholders solely for the purpose of imbuing the corporation with religious beliefs, with no other legal ramifications?

If the boundary between the corporation and its constituents is so porous as to allow for a "spillover" of religious identity, other questions arise. If the corporation is organized for the benefit of stockholders, should the stockholders themselves get to 
decide which religious practices the company observes? And if other constituencies are or should be relevant, as the Court suggests, why should a corporation's religious beliefs be defined solely by reference to stockholders, rather than managers, employees, or customers? Perhaps most important, if Citizens United allows corporations to limit externality regulation and inhibit the growth of the social safety net through the political process, and Hobby Lobby elevates the power of corporate managers over that of secular society, the argument that corporate law should focus only on stockholder welfare, rather than the best interests of all those affected by corporate behavior, is weakened.

\section{Our "Rhyming” Past}

According to Mark Twain, or at least according to those who claim Mark Twain said it, "history doesn’t repeat itself, but it rhymes." ${ }^{16}$ It's helpful to understand how we got to this point, so I will provide a brief retrospective of our "rhyming” past.

\section{A. The American Dream of Economic Autonomy vs. the American Reality of Employer Dominance}

\section{i. The Long Struggle Against So-Called "Wage Slavery”}

The United States is rightly associated with the desire to chart one’s own course, to provide for one's self and one's family independently. The idea of America as a place for small farmers who owned their own land and artisans who ran their own shops is genuine, and worthy of respect. ${ }^{17}$ But from early on, the American Dream didn't match

\footnotetext{
${ }^{16}$ The OXford Dictionary of American Quotations, Hugh Rawson \& Margaret Minder, eds., 316 (2d ed. 2006).

${ }^{17}$ See, e.g., Stanley Elkins \& ERIC McKitrick, The Age of Federalism: The Early AMERICAN REPUBLIC, 1788-1800 269 (1993) (quoting an essay by James Madison praising farmers: "The class of citizens who provide at once their own food and their own raiment, may
} 
the reality for many Americans. Many in the colonies worked for others, and large segments of the population were literally enslaved. ${ }^{18}$ Others were bound in servitude for some contractual period as indentured servants - including nearly half of English and Scottish immigrants who came to the U.S. through the 1770s. ${ }^{19}$

Even after the Civil War ended legal slavery in the United States, the typical employer-employee relationship was closer to servitude than the one characterized in current seminars teaching enlightened approaches to managing a company’s "Human

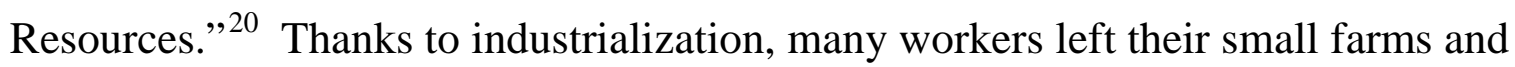
artisan shops for larger enterprises, in which they labored in a kind of quasi-feudal bondage. ${ }^{21}$ Employers, who the law called “masters," had extensive rights to control their employees - or legal "servants" - in almost all aspects of their lives. ${ }^{22}$ It was a criminal offense in some states to breach a labor contract prematurely. ${ }^{23}$

be viewed as the most truly independent and happy. They are more: they are the best basis of public liberty, and the strongest bulwark of public safety.... [T]he greater the proportion of this class to the whole society, the more free, the more independent, and the more happy must be the society itself.").

${ }^{18}$ On the eve of the Civil War, the U.S. Census found that there were nearly four million slaves, which amounted to roughly $14 \%$ of the total population. See Statistics of Slaves, available at http://www2.census.gov/prod2/decennial/documents/00165897ch14.pdf.

${ }^{19}$ Eric Foner, The Meaning of Freedom in the Age of Emancipation, 81 J. AM. HIsT. 435, 445 (1994).

${ }^{20}$ DAVID MONTGOMERY, CITIZEN WORKER: THE EXPERIENCE OF WORKERS IN THE UNITED States With Democracy and the Free Market During the Nineteenth Century (1995).

${ }^{21}$ Suresh Naidu \& Noam Yuchtman, How Green Was My Valley? Coercive Contract Enforcement in 19th Century Industrial Britain 6-9 (UCLA Economics Research Paper 2010), available at http://www.econ.ucla.edu/workshops/papers/History/Naidu.pdf.

${ }^{22}$ See ERIC FONER, THE STORY OF AMERICAN FREEDOM 19 (1994).

${ }^{23}$ See Bailey v. Alabama, 219 U.S. 219 (1911) (holding Alabama’s peonage laws unconstitutional under the Thirteenth Amendment). Similar laws were on the books in Florida and Georgia until the 1940s. See Pollock v. Williams, 322 U.S. 4 (1944); Taylor v. Georgia, 315 U.S. 25 (1942). 
It is perhaps unsurprising, then, that the rhetoric of the abolitionist movement spilled over into the realm of wage labor during the $19^{\text {th }}$ century. ${ }^{24}$ In a 1994 article that is characteristically incisive and comprehensive in scope, Professor Eric Foner outlined how slavery influenced our society's overall conception of freedom before and after the Civil War. Worker advocates drew on the concept of slavery to describe conditions of employment and economic dependence that left laborers with little opportunity to shape their own destinies. Terms such as "wage slavery” emerged to describe the limited power of workers. ${ }^{25}$ Professor Foner notes that Noah Webster’s American Dictionary defined freedom in opposition to slavery, as "a state of exemption from the power or control of another.” ${ }^{26}$ He quotes the spokesman for a group of former slaves: freedom is "placing us where we could reap the fruit of our own labor.”27 Professor Foner aptly concludes his article with a thought that resonates with our current condition:

[V]iewing the nineteenth century as a whole, the transition from slavery to freedom appears not simply as a narrative of liberation, but as a far more complex story in which the descendants of Africa came to enjoy greater freedom than they had known, but by no means freedom as they had come to understand it, while many small white farmers and craftsmen descended into the dependency of tenancy and wage labor, still experienced by many Americans as the antithesis of freedom. Emancipation, therefore, settled for all time [the] American paradox [identified by Professor Edmund S. Morgan], the simultaneous existence of slavery and freedom, while reopening another: the coexistence of political democracy and economic dependence. And that American paradox - the meaning of freedom in a land pervaded by inequality - still bedevils our society today. ${ }^{28}$

\footnotetext{
${ }^{24}$ Foner, supra note 19 , at $445-47$.

${ }^{25} \mathrm{Id}$. at 447.

${ }^{26} I d$.

${ }^{27}$ Id. at 458.

${ }^{28}$ Id. at 460 .
} 
As one example of this visceral inequality, into the early $20^{\text {th }}$ century, it was common practice in certain industries, including coal mining and steel, for employers to pay workers in scrip redeemable only at the company store, located in the company town where employees lived and worked. ${ }^{29}$ Food prices in company stores tended to be higher than elsewhere, and although workers were not literally forced to purchase from them in most cases, geographic isolation in the pre-automotive age and workers' lack of cash meant that they had no choice but to purchase staples on credit from their employers. ${ }^{30}$ Samuel Gompers, president of the American Federation of Labor, observed after a visit to Norwich, Connecticut, that "weeks and weeks and months and a year have passed where the workmen have not received a dollar in wages. They are practically bound there .... Under the system, they can not move; they are deprived of the right of American citizens, to move where they please ....”31 Corporate paternalism was not an incidental aspect of the scheme: paying workers in scrip, and controlling where they could live, enabled employers to police all aspects of their workers' lives.

For example, some companies required workers to attend church on Sundays. ${ }^{32}$ Indeed, historians have attributed religious revivals in the late $19^{\text {th }}$ century to the efforts of employers: “the most powerful source of the workingmen's revival was the simple,

${ }^{29}$ Company Stores and the Scrip System, 41 Monthly LAB. Rev. 45, 45 (1935).

${ }^{30} \mathrm{Id}$.

${ }^{31}$ U.S. DePARTMENT OF LABOR, GROWTH OF LABOR LAW IN THE United STATES 91 (1962).

${ }^{32}$ See, e.g., TAMARA K. HAREVEn, FAmily Time \& Industrial Time: The Relationship BETWEEN THE FAMILY AND WORK IN A NEW ENGLAND INDUSTRIAL COMMUNITY 55 (1993) (discussing required church attendance in the company towns of Lowell and Manchester, Massachusetts); DANIEl NelSON, AMERICAN RUBBER WORKERS \& ORGANIZED LABOR, 1900194111 (1988) (discussing the Goodyear Metallic Co.'s required church attendance policy in the late $19^{\text {th }}$ century). 
coercive fact that many wage earners worked for men who insisted on seeing them in church.”33 Many other employers banned liquor - not just in the company store, but even in independent stores near the town. According to one historian, "Some employers felt that their position gave them the right and the responsibility to be paternalistic, that it was their mission to lead laborers to a better life. Often this better life meant keeping the town dry.”34 One factory owner vowed to make his workers "good citizens” by keeping "whiskey and beer from the mouth of the working man." 35 Another testified before the U.S. Industrial Commission that setting only monthly paydays, and then paying workers in scrip, was done expressly to "mitigate the impact of the saloon.” 36 The self-reported motives of employers like this were often unimpeachable: according to the company manager of one town, "We keenly and genuinely feel our responsibility toward that which has been entrusted to us. We believe in the dignity of man and the worth of the individual. ${ }^{37}$

George Pullman, the founder of the Pullman Palace Car Company, was particularly notable for his “benevolent” paternalism. ${ }^{38}$ At its peak in 1893, 12,500 people lived in the town of Pullman, Illinois, built and designed to house the Company's

\footnotetext{
${ }^{33}$ Carol Sheriff, The Artificial River: The Erie Canal and the Paradox of Progress, 1817-1862 157 (1996).

${ }^{34}$ Linda CARLSON, COMPANY TOWNS OF THE PACIFIC NORTHWEST 10 (2003).

${ }^{35}$ Grace Hooten Gates, The Model City of the New South: Anniston, Alabama, 1872190044 (1996).

${ }^{36}$ John J. Rumbarger, Profits Power, ANd Prohibition: Alcohol Reform and the INDUSTRIALIZING OF AMERICA, 1800-1930 130 (1989).

${ }^{37}$ M. Todd Henderson, The Nanny Corporation, 76 U. CHI. L. Rev. 1517, 1535 (2009) (quoting James B. Allen, The Company TOWn In the American West 123 (1966)).

${ }^{38}$ IDA M. TARBELL, NeW IDEALS IN Business 146 (1916).
} 
workers. ${ }^{39}$ The Pullman Company not only owned the town, it also prohibited workers from owning their own homes, and dictated how those workers had to maintain their rented houses. ${ }^{40}$ Life in the town of Pullman reflected George Pullman's moral standards: "Brothels, dance halls, and gambling establishments were banished, and liquor was available only in a hotel patronized by visitors rather than the resident workers.” ${ }^{41}$ How workers looked was also part of Pullman’s scheme. According to an 1893 Company publication:

The Pullman workingman has developed into a distinctive type - distinct in appearance, in tidiness of dress, in fact in all of the external indications of self-respect. ... [A] representative gathering of Pullman workers would be quite forty per cent better in evidence of thrift and refinement and in all the outward indications of a wholesome habit of life, than would be a representative gathering of any corresponding group of workingmen which could be assembled elsewhere in the country.

\section{ii. A Counterweight to Corporate Power Emerges}

As more and more Americans were forced to provide for themselves by working for large employers like Pullman, the labor movement emerged as a counterweight to corporate power. One of the movement's objectives was to limit corporate paternalism to ensure that workers could spend their wages as they pleased and have some free time in which to do so. In advocating for these changes, the labor movement reflected growing discontent by contemporary observers and workers themselves. Richard T. Ely sharply critiqued Pullman’s “social experimentation” in 1885, arguing that offering "the gilded

\footnotetext{
${ }^{39}$ Almont Lindsey, Paternalism and the Pullman Strike, 44 Am. HIST. Rev. 276 (1939).

${ }^{40} \mathrm{Id}$. at 272.

${ }^{41}$ Paul S. Boyer, Urban Masses and Moral Order in America, 1820-1920 144 (1992).

${ }^{42}$ Hugh Dalziel Duncan, Culture and Democracy 166 (1989).
} 
cage as a substitute for personal liberty” was fundamentally "un-American." ${ }^{43}$ An 1890s study of Pullman employees found a "concentrated hatred" of the company because of its efforts to regulate every aspect of their lives. ${ }^{44}$

Before 1894, the concerns of Pullman’s workers were kept largely underground.

Ely observed:

Here is a population of eight thousand souls where not one single resident dare speak out openly his opinion about the town in which he lives. One feels that one is mingling with a dependent, servile people. There is an abundance of grievances, but if there lives in Pullman one man who would give expression to them in print over his own name, diligent inquiry continued for ten days was not sufficient to find him. ${ }^{45}$

But the rise of labor unions gave a louder voice to these "grievances" and

ultimately achieved some freedom for workers, in Pullman and elsewhere. Unions targeted the use of scrip and in-kind payment, which they saw "as an example of 'wage slavery,' a practice exploitative of poor, unskilled workers and their families." ${ }^{46}$ In Pullman's case, the American Railway Union capitalized on widespread worker resentment after a sharp downturn in economic conditions was greeted with callous indifference by the company, which refused to lower rent despite cutting wages by an average of 25\%. ${ }^{47}$ The famous Pullman Strike of 1894 brought Pullman's experiment to

${ }^{43}$ Richard T. Ely, Pullman: A Social Study, 70 HaRPeR's New Monthly Magazine 465-66 (1885), available at http://publications.newberry.org/pullman/items/show/89.

${ }^{44}$ Matthew W. Finkin, Employee Privacy, American Values, and the Law, 72 CHI.-Kent L. ReV. 221, 251, n.152 (1996) (quoting STUART D. BRANDES, AMERICAN WELFARE CAPITALISM, 18801940139 (1976)).

${ }^{45}$ Ely, supra note 43 , at 464.

${ }^{46}$ Laura Phillips Sawyer, Contested Meanings of Freedom: Workingmen's Wages, the Company Store System, and the Godcharles v. Wigeman Decision, 12 J. GILDED Age \& Progressive ERA 285, 286-87 (2003).

${ }^{47}$ Lindsey, supra note 39, at 286. 
an end. The Strike, and George Pullman's pitiless response to his workers' hardship, led Illinois’ attorney general to sue the Pullman Company for operating a town in violation of its corporate charter. The Illinois Supreme Court agreed in $1898 .^{48}$

Even with the growth of unions, though, legal guarantees of freedom for workers evolved slowly. At first, freedom meant something as basic as the right to be paid at regular intervals. Massachusetts passed the first guaranteed wage law in the United States in 1879, which required that "cities shall, at intervals not exceeding seven days, pay all laborers who are employed by them . . . if such payment is demanded."49

Laws requiring workers to be paid in cash rather than company scrip were enacted around the same time, also first at the state level. Even these minimal efforts met resistance, ironically in the name of freedom. Pennsylvania was the first state to prohibit the use of company scrip to pay “wages,” but the Pennsylvania Supreme Court declared that ban unconstitutional on the grounds that it infringed the "right of the employer and the employee [because the employee] may sell his labor for what he thinks best, whether money or goods ....”50 One union leader quipped that the court defined “the workman’s liberty" as "the right 'to accept merchandise in lieu of money.",51 But with the support of unions, other states soon began to pass their own laws requiring that workers be paid in

${ }^{48} \mathrm{Id}$. at 288.

${ }^{49}$ U.S. DEPARTMENT OF LABOR, GROWTH OF LABOR LAW IN THE UNITED STATES 89 (1962).

${ }^{50} \mathrm{Id}$. at 90.

${ }^{51}$ ERIC Foner, The StOry OF AMERICAN FreEdom 123 (1994). 
cash wages. By 1914, “44 jurisdictions had some type of wage payment law,” although many of them applied only to workers in specific industries. ${ }^{52}$

\section{iii. Ford's Feudal System}

In keeping with the pattern of slow, incremental change, these limited legal reforms did not completely eliminate corporate paternalism. In 1914, the Ford Motor Company famously began offering workers five dollars a day, over twice the average wage for the time. ${ }^{53}$ But workers were only eligible for the higher wage if they conformed to Henry Ford's religious and moral ideals. The company's “Sociological Department” investigated and evaluated workers and their families to ensure that workers did "not debauch the additional money [they] receive[]."54 Investigators would visit workers' houses, conduct interviews, and perform inspections to determine if workers were living their lives according to middle class, Protestant values. Workers were expected to stay sober, get married after a certain age, save their money, and go to church - and Ford's agents took attendance on Sundays to prove it. ${ }^{55}$ Cooperation was rewarded with additional pay; lack of compliance deterred by wage penalties or the threat of discharge. All of this was motivated, according to Henry Ford, by his "heartfelt, personal

${ }^{52} I d$. at 91 . My own home state of Delaware did not pass any wage law until the 1950s, and then only to require biweekly payments to railroad employees. Id. at 93.

${ }^{53}$ Leonard I. Rotman, Debunking the 'End of History' Thesis for Corporate Law, 33 B.C. INT'L \& Comp. L. Rev. 219, 234, n.87 (2010); Martha May, The Historical Problem of the Family Wage: The Ford Motor Company and the Five Dollar Day, 8 Feminist StUdiEs 399, 409 (1982). ${ }^{54} \mathrm{M}$. Todd Henderson, The Story of Dodge v. Ford Motor Company, in CORPORATE LAW StORIEs 37, 51 (J. Mark Ramseyer ed., 2009).

${ }^{55}$ Robert P. Weiss, Corporate Security at Ford Motor Company: From the Great War to the Cold War, in CORPORATE SECURITY IN THE $21^{\text {ST }}$ CENTURY 21 (Kevin Walby \& Randy Lippert eds. 2014). 
interest in the welfare of his employees." ${ }^{56}$ A contemporary of Ford's described his efforts to create a "corporation with a soul” that "set justice and humanity above profits and production." 57

Some employees and commentators were resistant to Ford's benevolence, just as they had been to Pullman's a generation before. Sociological Department investigators found "a lot of apathy and ill-feeling."58 Even though they risked being fired, some Ford employees refused to submit to investigations of their bodily cleanliness or their marital status. ${ }^{59}$ According to one observer, "employees usually preferred to take charge of their own lives and found paternalism intrinsically demeaning. By regarding himself as a father to his employees and acting accordingly, an employer unavoidably relegated them to an inferior, childlike position.”60

There were also contemporaneous critics outside of the Ford Motor Company who were concerned about infantilizing employees. According to a 1914 newspaper editorial entitled "Ford's Feudal System":

It is the American theory that when his day's work is over a free man is free ... that so long as a man observes his obligations to society he is his own master in his own house. The payment of good wages does not give an employer the authority to seek to regulate the internal family affairs of any man. ${ }^{61}$

${ }^{56}$ Steven Watts, The People's Tycoon 220 (2005).

${ }^{57} \mathrm{Id}$. at 214.

${ }^{58} I d$. at 221.

${ }^{59}$ Finkin, supra note 44 , at 250-51.

${ }^{60} I d$. at 251, n.152 (quoting BRANDES at 140-41).

${ }^{61}$ Steven Watts, The PeOPle’s Tycoon 220 (2005) (quoting Ford's Feudal System, St. Albans Messenger, May 13, 1914). 
Eventually, concerns about Ford and other employers, coupled with increased resistance to economic exploitation, prompted legal reform. Even Henry Ford himself abandoned his scheme, asserting in his 1922 memoirs that "paternalism has no place in industry. Welfare work that consists in prying into employees’ private concerns is out of date.”62

\section{iv. “Necessitous Men are Not Free Men”}

As part of President Roosevelt's New Deal, several state-level labor reforms became federal law. Roosevelt's administration and fellow liberals in Congress proposed fundamental changes to the paradigm of labor-management relations, particularly to ensure that low-wage workers were not deprived of a living wage. ${ }^{63}$ For example, the Fair Labor Standards Act of 1938 (FLSA) prohibited payment in "scrip, tokens, credit cards, 'dope checks,' coupons, and similar devices.” ${ }^{64}$ In passing the law, Congress recognized that "the individual worker should have both the freedom and the responsibility to allocate his minimum wage among competing economic and personal interests," as one court phrased it. ${ }^{65}$

The FLSA was just one piece of the larger New Deal and later Fair Deal reforms that constituted the foundation of an expanded social safety net. The National Labor Relations Act, enacted in 1935, gave workers the right to form unions and collectively

\footnotetext{
62 Henderson, supra note 37, at 1542 (quoting HENRY FORD, My LIFE AND WORK 130 (1922)).

${ }^{63}$ Walter M. Luers, Workfare Wages Under the Fair Labor Standards Act, 67 FORDHAM L. REV. 203, 208 (1998).

6429 U.S.C. § 201 et seq.

${ }^{65}$ Brennan v. Heard, 491 F.2d 1, 4 (5th Cir. 1974), overruled on other grounds by McLaughlin v. Richland Shoe Co., 486 U.S. 128, 134-35 (1988)).
} 
bargain for wages. ${ }^{66}$ The Social Security Act of 1935 provided for old age insurance and welfare payments for the poor, and encouraged states to set up unemployment coverage. ${ }^{67}$ The GI Bill gave veterans housing, education and other subsidies that became a model for later programs. ${ }^{68}$ As Roosevelt declared in his "Second Bill of Rights" speech in 1944, "We have come to a clear realization of the fact that true individual freedom cannot exist without economic security and independence.

'Necessitous men are not free men.' People who are hungry and out of a job are the stuff of which dictatorships are made." ${ }^{69}$

\section{B. Opting Out, v.1: The History of Religious Objections to the Welfare State}

In response to the emergence of this larger social welfare state, primarily funded by taxes and other schemes annexed to employment, some employers objected that funding certain secular causes burdened their religious beliefs. In nearly every case, the court respectfully assumed the sincerity of the employer's objections, but then found that society’s interest in a secular system of laws overcame them. ${ }^{70}$ The guiding principle was articulated by the U.S. Supreme Court in 1940: the First Amendment "embraces two

${ }^{66} 29$ U.S.C. $\S \S 151-169$.

6742 U.S.C. ch. 7.

${ }^{68}$ Servicemen's Readjustment Act of 1944, ch. 268, 58 Stat. 284.

${ }^{69}$ Franklin D. Roosevelt, Annual Message to Congress on the State of the Union, Jan. 11, 1944, available at http://www.presidency.ucsb.edu/ws/index.php?pid=16518.

${ }^{70}$ See, e.g., James E. Ryan, Smith and the Religious Freedom Restoration Act: An Iconoclastic Assessment, 78 VA. L. REv. 1407 (1992) (noting that religious claimants "rarely succeeded under the compelling interest test" - including only four of the seventeen claims in the Supreme Court (including three that involved unemployment compensation) and twelve of the ninety-seven claims in federal courts of appeals (including five brought by prisoners)); Elizabeth Sepper, Gendering Corporate Conscience, 38 HARV. J. OF L. \& GENDER (forthcoming 2014), at 4; 6, n. 24 (cataloguing refusals by the courts to grant exemptions to commercial businesses from secular laws for religious reasons). 
concepts - freedom to believe and freedom to act. The first is absolute but, in the nature of things, the second cannot be. Conduct remains subject to regulation for the protection of society."71

Accordingly, federal courts rejected a series of religious objections by employers to federal social welfare and tax statutes. When Seventh Day Adventists refused to pay Social Security taxes, the Tax Court did not doubt the sincerity of their objections, but found that "in exercising its constitutional function and duty to provide for the general welfare, a legislature may often formulate a program which places some indirect burden on the free exercise of some religious beliefs." ${ }^{\text {72 }}$ Likewise, the Tax Court did not question a devotee of the Sai Baba faith’s opposition to life, retirement, and medical insurance on religious grounds, but found that she was nonetheless liable for selfemployment income taxes. ${ }^{73}$ The court was not persuaded that the devotee merited an exemption simply because Congress had provided exemptions from those same taxes to licensed ministers, quoting the Supreme Court's decision in Carmichael v. Southern Coal: "It is inherent in the exercise of the power to tax that a state be free to select the subjects of taxation and to grant exemptions. This Court has repeatedly held that inequalities which result from ... singling out ... one particular class for taxation or exemption [] infringe no constitutional limitation.”74

${ }^{71}$ Cantwell v. Connecticut, 310 U.S. 296, 303-304 (1940).

${ }^{72}$ Palmer v. Comm'r, 52 T.C. 310 (1969).

${ }^{73}$ Henson v. Comm'r, 66 T.C. 835 (1976).

${ }^{74}$ Id. (quoting Carmichael v. S. Coal Co., 301 U.S. 495, 500 (1937)). 
Similarly, the First Circuit held in 1954 that a religious corporation, whose

business involved printing religious materials, was not exempt from the FLSA:

Here we have a remedial measure seeking to insure to the workers of the United States engaged in the production of goods for commerce a minimum wage sufficient to maintain a minimum standard of living which Congress deemed to be necessary to their well-being. We can find no reason for holding that the employees of a church corporation, who work in a printing establishment owned and operated by the corporation, should not be entitled to the benefits of this remedial legislation....

While the First Amendment to the Constitution does guarantee the free exercise of religion, the right so guaranteed is not without limitations. The individual has the absolute power to believe in any religious doctrine he may choose but only limited power to act pursuant to that belief. As said in Gara v. United States . . .: "The guaranty of freedom of religion in the Bill of Rights is not a guaranty of immunity for violation of law."75

One of the most prominent decisions in this line of cases was United States v. Lee, authored by Chief Justice Burger on behalf of a unanimous Court in $1982 .^{76}$ Lee was a member of the Old Order Amish, which opposes the Social Security system as a matter of religious faith. Lee thus objected to paying Social Security taxes for his employees. ${ }^{77}$ Although Congress had provided an exemption from such taxes for self-employed Amish individuals, the Court held that the exemption did not extend to employers. That is, employers had to provide their workers with the protections guaranteed by the Social

${ }^{75}$ Mitchell v. Pilgrim Holiness Church Corp., 210 F.2d 879, 884 (7th Cir.), cert. denied, 347 U.S. 1013 (1954); see also Tony and Susan Alamo Found. v. Sec'y of Labor, 471 U.S. 290 (1985) (holding that a non-profit religious foundation's commercial activities were covered by the Fair Labor Standards Act, and that application of the Act to the foundation and its employees did not violate the Free Exercise or Establishment Clauses); DeArment v. Harvey, 932 F.2d 721 (8th Cir. 1991) (holding that the First Amendment does not preclude application of the Fair Labor Standards Act to lay teachers at a church school); Dole v. Shenandoah Baptist Church, 899 F.2d 1389 (4th Cir.), cert. denied, 498 U.S. 846 (1990) (holding that the Fair Labor Standards Act applied to church-operated schools and employees).

${ }^{76}$ United States v. Lee, 455 U.S. 252 (1982). Justice Stevens wrote a concurring opinion. ${ }^{77}$ Id. 
Security Act, regardless of the employers' religious objection. The Court did not doubt the sincerity of Lee's beliefs, or his legitimate religious objection to Social Security, but found that the government's interest in a uniform system - and the employee's interest in receiving those benefits - overrode those objections:

Congress and the courts have been sensitive to the needs flowing from the Free Exercise Clause, but every person cannot be shielded from all the burdens incident to exercising every aspect of the right to practice religious beliefs. When followers of a particular sect enter into commercial activity as a matter of choice, the limits they accept on their own conduct as a matter of conscience and faith are not to be superimposed on the statutory schemes which are binding on others in that activity. Granting an exemption from social security taxes to an employer operates to impose the employer's religious faith on the employees. ${ }^{78}$

In so doing, the Court followed the analysis it had previously set out in Wisconsin $v$. Yoder $^{79}$ and Sherbert $v$. Verner ${ }^{80}$ : balancing the petitioner's religious belief against the government's interest. ${ }^{81}$ Notwithstanding the sincerity of Lee's beliefs, the Court determined that the government’s interest “in assuring mandatory and continuous participation in and contribution to the social security is very high." ${ }^{82}$ Allowing religious employers to opt out of the system would "unduly interfere with fulfillment" of that interest. ${ }^{83}$

\section{The Movement for Minimum Essential Guarantees of Economic Security, Dignity, and Freedom Includes Access to Healthcare as a Fundamental Right}

\footnotetext{
${ }^{78} I d$. at 261.

${ }^{79} 406$ U.S. 205 (1972).

80374 U.S. 398 (1963).

${ }^{81}$ Lee, 455 U.S. at 259.

${ }^{82} \mathrm{Id}$.

${ }^{83}$ Id.
} 
The Social Security Act that Lee objected to was not the only controversial element of FDR's broader vision for society. One of the "Rights" he identified in his Second Bill of Rights speech was " $[t]$ he right to adequate medical care and the opportunity to achieve and enjoy good health.”84 But despite its vast scope, the New Deal ultimately did not include any health insurance-related provisions, in large part because of the opposition of the American Medical Association. ${ }^{85}$

Harry S. Truman promised his own "Fair Deal” in 1949, first praising the efforts of his predecessors in establishing "a system of social security. We have enacted laws protecting the rights and the welfare of our working people .... [These policies] have strengthened the material foundations of our democratic ideals. Without them, our present prosperity would be impossible." ${ }^{86}$ He then charged Congress with fixing many of the "shortcomings" he identified, particularly raising the minimum wage, strengthening the Department of Labor, and increasing Social Security benefits and broadening its coverage. But most relevant for present purposes was the challenge that President Truman posed:

We must spare no effort to raise the general level of health in this country. In a nation as rich as ours, it is a shocking fact that tens of millions lack adequate medical care. ... [W] [Weed - and we must have without further delay - a system of prepaid medical insurance which will enable every American to afford good medical care. ${ }^{87}$

\footnotetext{
${ }^{84} \mathrm{Id}$.

${ }^{85}$ See, e.g., Doctors Condemn Health Insurance, N.Y. TIMES, June 13, 1934; SocIAL SECURITY Administration, The Evolution OF Medicare: Chapter 2: The SECOND Round-1927 TO 1940, available at http://www.ssa.gov/history/corningchap2.html.

${ }^{86}$ Harry S. Truman, Annual Message to the Congress on the State of the Union, Jan. 5, 1949, available at http://www.presidency.ucsb.edu/ws/?pid=13293.

${ }^{87}$ Id.
} 
Congress did not agree, and rejected President Truman's vision for a national health insurance system. In a statement whose theme opponents of the ACA would later echo, Republican Senator Robert A. Taft declared that he considered the national health bill to be "socialism. It is to my mind the most socialistic measure this Congress has ever had before it." ${ }^{88}$

But in 1960, John F. Kennedy revived New Deal liberalism in promising a "New Frontier" of social and economic reform. Like President Truman, he vowed to raise the minimum wage and broaden its coverage, increase Social Security benefits, and provide for the elderly and those living in poverty. ${ }^{89}$ President Lyndon Johnson, whose hero was FDR, put his political muscle and skill behind his ambitious "Great Society” program. LBJ carried out many reforms: expanding the safety net to include explicit guarantees of healthcare, providing for the elderly through the Medicare program and the poor through the Medicaid program. ${ }^{90}$ And, of course, the money to pay for these programs - just like Social Security originally - came out of the paychecks of all workers, as taxes split between the employee and the employer. ${ }^{91}$ In essence, these taxes were considered part of the minimum wage guaranteed to an employee to be devoted to a safety net. Everyone

\footnotetext{
${ }^{88}$ Monte M. Poen, Harry S. Truman Versus the Medical Lobby: The Genesis of MEDICARE 88 (1996).

${ }^{89}$ U.S. DEPT. OF LABOR, ChAPTER 6: ERAS OF THE NEW Frontier AND THE GREAT SOCIETy, 1961-1969, available at http://www.dol.gov/dol/aboutdol/history/dolchp06.htm.

${ }^{90}$ Social Security Amendments of 1965, 79 Stat. 286 (1965).

${ }^{91}$ Noah Meyerson, How Does Social Security Work?, Congressional Budget Office (Sept. 19, 2013), http://www.cbo.gov/publication/44590.
} 
with a job had to pay into the common pool, and those same workers were then entitled to the benefits afforded by the scheme, as long as they met the eligibility requirements.

But the broader idea of mandatory health coverage for everyone - not just the elderly and the desperately poor - was still unrealized. To move toward this goal, Richard Nixon introduced his own plan requiring employers to provide minimum insurance coverage in $1971 .^{92}$ Jimmy Carter campaigned in 1976 on a promise to establish a "comprehensive national health insurance system with universal and mandatory coverage.”93 Bill Clinton declared in 1993 that "we must make this our most urgent priority: giving every American health security, health care that can never be taken away, health care that is always there."94 Even after Clinton’s plan for universal healthcare was defeated, Republicans also advanced ideas to increase access to health insurance and decrease the number of "free-riders" who used the healthcare system when sick, but did not pay premiums, thus shifting their medical costs to other employees, employers, and taxpayers generally. To deal with such free-riding, the Heritage Foundation initially advocated the adoption of individual insurance mandates. ${ }^{95}$ Senior

${ }^{92}$ Mr. Nixon's Health Plan, N.Y. Times, Feb. 19, 1971.

${ }^{93}$ Democratic Party Platform of 1976 (July 12, 1976), available at http://www.presidency.ucsb.edu/ws/?pid=29606.

${ }^{94}$ William J. Clinton, President's Address to Congress on Health Care, Sept. 23, 1993, available at http://www.nytimes.com/1993/09/23/us/clinton-s-health-plan-transcript-president-s-addresscongress-health-care.html.

95 Stuart M. Butler, Why Conservatives Need a National Health Plan, HeRITAGE FoundATION (March 22, 1993), available at http://www.heritage.org/research/lecture/why-conservativesneed-a-national-health-plan; Stuart M. Butler, Assuring Affordable Health Care for All Americans, HERITAGE FOUNDATION (Oct. 1, 1989), available at http://www.heritage.org/research/lecture/assuring-affordable-health-care-for-all-americans. The Foundation later strongly disavowed that approach, including in an amicus curiae brief addressing the constitutionality of the Affordable Care Act. Florida ex rel. Atty. Gen. v. U.S. 
Republican leaders, including Senator Bob Dole and Representative Newt Gingrich, vocally supported that approach to control healthcare costs and expand coverage. ${ }^{96}$

Calls for expanding coverage came against an international background in which most of our capitalist allies and peers had already established access to health coverage as a basic right. ${ }^{97}$ England began providing universal coverage through its National Health Service in 1948, after proponents argued that "health was a right, not a commodity to be bought or sold, or subject to market forces." 98 The same themes resonated in Canada, which first enacted its government-funded universal health insurance program by legislation in 1957: health services are "an integral part of the life of every Canadian. ... [P]eople are thinking of health as a right of citizenship.”99 Japan followed suit in

Dep't of Health \& Human Servs., 648 F.3d 1235, 1359 (11th Cir. 2011), aff'd in part, rev'd in part sub nom. Nat'l Fed'n of Indep. Bus. v. Sebelius, 132 S. Ct. 2566 (2012). ${ }^{96}$ See Michael Cooper, Conservatives Sowed Idea of Health Care Mandate, Only to Spurn It Later, N.Y. TiMES (Feb. 14, 2012); Health Equity and Access Reform Today Act, S. 1770, 103d Cong. (1993) (bill requiring employers "to make available, either directly, through a purchasing group, or otherwise, enrollment in a qualified health plan to each eligible employee," sponsored by Sen. John Chafee (R-RI) with 19 Republican cosponsors); Consumer Choice Health Security Act, S. 1743, 103d Cong. (1993) (bill requiring employers to withhold insurance premiums from worker paychecks and remit funds to the employees' chosen insurer, sponsored by Sen. Don Nickles (R-OK) with 24 Republican cosponsors).

${ }^{97}$ See, e.g., William D. Savedoff \& Amy L. Smith, Achieving Universal Health Coverage: Learning from Chile, Japan, Mayalsia and Sweden (Results for Development Institute, Working Paper, Dec. 2011), available at http://r4d.org/sites/resultsfordevelopment.org/files/THF\%20\%20Progress\%20toward\%20universal\%20health\%20coverage.pdf.

${ }^{98}$ Sally Sheard, A Creature of Its Time: The Critical History of the Creation of the British NHS, 8 MichAeL Q. 428, 434 (2011).

${ }^{99}$ Making Medicare: The History of Health Care in Canada, 1914-2007: Fundamental Principles, CANADIAN MUSEUM OF HistoRY, http://www.historymuseum.ca/cmc/exhibitions/hist/medicare/medic-3h11e.shtml (quoting Canadian Federation of Agriculture, Health on the March, Jan. 1943). 
$1961,{ }^{100}$ and Australia in $1975 .{ }^{101}$ Among OECD countries, ${ }^{102}$ only the U.S., Mexico, and Turkey did not have universal coverage as of 2007 - and Turkey's public insurance program covered two-thirds of its citizens, Mexico's one-half. ${ }^{103}$ The comparable figure in the U.S. before the ACA was 27\%. ${ }^{104}$ And Turkey adopted a universal health care system in 2008; ${ }^{105}$ Mexico, which began the road to universal coverage in 2004, covered all of its citizens as of 2012. ${ }^{106}$ From this comparative and historical perspective, then, the Affordable Care Act could be seen as the next logical step in a historical progression.

\section{An Accident of History and Tax Law: The American System of Employer-Based Health Insurance}

Because the move toward universal health care came slowly in the U.S., efforts to expand coverage naturally took into account the preexisting market arrangements for health insurance. Without a system of government-provided health insurance, the U.S.

${ }^{100}$ Yasuki Kobayashi, Five Decades of Universal Health Insurance Coverage in Japan: Lessons and Future Challenges, 52 JAPANESE MED. Ass'N J. 263 (2009), available at https://www.med.or.jp/english/journal/pdf/2009_04/263_268.pdf.

${ }_{101}$ Melissa Hilless \& Judith Healy, EuRopean OBSERVATORY on HeAlth CARE SySTEMS, Health Care Systems in Transition: Australia 15 (2001), available at http://www.euro.who.int/_data/assets/pdf_file/0008/96434/E74466.pdf.

${ }^{102}$ The OECD, or Organisation for Economic Co-operation and Development, is composed of most of the world's nations who have a form of democratically elected government and a market-based economic system. It includes not only nations like Australia, Japan, Sweden, and the United States, but also "emerging" economies like Chile, Mexico, the Slovak Republic, Slovenia, and Turkey. Members and Partners, OECD, http://www.oecd.org/about/membersandpartners/ (last visited Nov. 13, 2014).

${ }^{103}$ OECD, HEALTH AT A GLANCE, 2009: OECD InDiCATORS 144 (2009), available at http://dx.doi.org/10.1787/health_glance-2009-61-en.

${ }^{104} I d$.

${ }^{105}$ See Rifat Atun, et al., Universal Health Coverage in Turkey: Enhancement of Equity, 382 THE LANCET, 65 (July 6, 2013) ("Turkey has successfully introduced health system changes and provided its citizens with the right to health to achieve universal health coverage, which helped to address inequities in financing, health service access, and health outcomes.").

${ }^{106}$ See Felicia Marie Knaul, et al., The Quest for Universal Health Coverage: Achieving Social Protection for All in Mexico, THE LANCET.COM (Aug. 16, 2012), http://download.thelancet.com/flatcontentassets/pdfs/S014067361261068X.pdf. 
had developed an alternate system to deliver health insurance, under which workers primarily obtained coverage through their jobs. Employer-based health insurance began as a way to evade wage controls imposed during World War II; employers saw health insurance as a fringe benefit that could entice valuable employees without running afoul of the War Production Board. ${ }^{107}$ At the time, health insurance coverage was a luxury: only $9 \%$ of the population had any form of coverage as of $1940 .{ }^{108}$

But tax policy spread the growth of this fringe perk. Because health insurance was not considered by the IRS as part of gross income for tax purposes, "paying” in health benefits meant that employees could receive some of their wages essentially tax-free. ${ }^{109}$ Especially for those with higher incomes and thus higher marginal tax rates, this was a material benefit. At the same time, employers could deduct the cost of health insurance as a business expense. ${ }^{110}$ As a result, by 2010 , almost $60 \%$ of Americans received health insurance through their employers; among those in the labor force, over 70\% did so. ${ }^{111}$ Nonetheless, $18 \%$ of workers lacked health insurance and nearly 5\% relied on public health insurance. Those figures are not nearly as high as the $50 \%$ of the unemployed who did not have insurance or the $16 \%$ who used Medicare or Medicaid, but the "working but

${ }^{107}$ RICHARD E. SCHUMANN, BUREAU OF LABOR STATISTICS, COMPENSATION FROM WORLD WAR II THROUGH THE GREAT SOCIETY (2011), available at http://www.bls.gov/opub/mlr/cwc/compensation-from-world-war-ii-through-the-greatsociety.pdf.

${ }^{108}$ Robert B. Helms, Tax Policy and the History of the Health Insurance Industry (Feb. 29, 2008), available at http://www.taxpolicycenter.org/tpccontent/healthconference_helms.pdf. ${ }^{109}$ IRS rules treated fringe benefits differently from cash wages, but the provision related to health insurance was not adopted as statutory law until 1954. I.R.C. § 106 (1954).

${ }^{110}$ According to one estimate, the cost of the business deduction was $\$ 4.8$ billion in 2007; the exclusion from employee income was estimated as $\$ 133.8$ billion. Helms, supra note 108 , at 18 .

${ }^{111}$ Hubert Janicki, United States Census BuREau, EMPloyment-BASEd HeAlth INSURANCE: 2010 3, available at http://www.census.gov/prod/2013pubs/p70-134.pdf. 
uninsured" still represented a large swath of the population. ${ }^{112}$ And, following the Great Recession, the ranks of these uninsured were growing. ${ }^{113}$

For the most part, these uninsured workers were wage-earners whose jobs did not come with health insurance. According to the Kaiser Family Foundation, before the Affordable Care Act took effect, over $70 \%$ of the uninsured had one or more full-time workers in their family. ${ }^{114}$ And contrary to the common misconception, Medicaid did not cover even the majority of the poorest Americans. ${ }^{115}$ Only one-third of those below the poverty level - which at the time the ACA was enacted, equated to $\$ 21,200$ for a family of four ${ }^{116}$ - were covered by Medicaid in 2008, because of Medicaid's strict eligibility limits. ${ }^{117}$ The uninsured were often workers who did not fall into one of the specific categories of mandatory coverage or who made too much to qualify for Medicaid, but whose employers did not provide insurance, and who could not afford to purchase it on

${ }^{112} I d$.

${ }^{113}$ Robin A. Cohen, Ph.D., \& Michael E. Martinez, Center for Disease Control, Health INSURANCE COVERAGE: EARLY RELEASE OF ESTIMATES From THE NATIONAL HEALTH INTERVIEW SURVEY, JANUARY-MARCH 2013 (Sept. 2013), at 2, available at http://www.cdc.gov/nchs/data/nhis/earlyrelease/insur201309.pdf.

${ }^{114}$ Key Facts About the Uninsured Population, Fig. 4, KAISER FAmiLy Foundation, available at http://kff.org/uninsured/fact-sheet/key-facts-about-the-uninsured-population/ (last visited Nov. 5, 2014).

${ }^{115}$ See, e.g., Medicaid: Issues of Eligibility and Enrollment, available at http://www.healthbeatblog.com/2008/10/medicaid-issues/.

${ }^{116}$ In the 48 Contiguous States and D.C. Department of Health \& Human Services, 2008 HHS POVERTY GUIDELINES, available at http://aspe.hhs.gov/poverty/08poverty.shtml.

${ }^{117}$ Before the Affordable Care Act, the federal government required states to cover certain populations (children, individuals with disabilities, seniors, parents, and pregnant women) as long as they fell below certain income cutoffs. Individual states could then choose to expand coverage to non-elderly adults without disabilities or to expand coverage slightly above the federal income cutoffs by seeking a waiver from the federal government. See Counsel OF State Governments, MEDicAid 101: A PRiMER FOR STATE Legislators (Jan. 2009), available at http://www.csg.org/knowledgecenter/docs/Medicaid_Primer_final_screen.pdf. 
the open market. Coverage for part-time employees was particularly spotty: only $13 \%$ of part-time workers received health insurance through their employers. ${ }^{118}$ And many employers intentionally employed workers on a "full part-time" basis; that is, at as many hours a week as possible without enabling the employee to be eligible for health insurance. $^{119}$

A report by the Institute of Medicine found that in 2000 alone, 18,000 Americans between the ages of 25 and 64 died because they did not have health insurance. ${ }^{120}$ By 2010 , that yearly estimate of premature deaths was 26,100 . That equates to three people who died each hour because they delayed or went without preventative or needed medical care. $^{121}$ The Affordable Care Act itself states that the economy lost $\$ 207$ billion every year "because of the poorer health and shorter lifespan of the uninsured." 122

The ACA sought to remedy this situation in complicated ways, but essentially it combined an expansion of Medicaid with an individual mandate to purchase insurance, and a separate employer mandate designed to give employers a strong financial incentive

\footnotetext{
118 JANICKI, supra note 111 , at 11.

${ }^{119}$ See, e.g., Michael Barbaro \& Reed Abelson, A Health Plan for Wal-Mart: Less Stinginess, N.Y. TIMES, Nov. 13, 2007, available at http://www.nytimes.com/2007/11/13/business/13walmart.html (describing Walmart's efforts to reduce healthcare costs, including by limiting workers' hours).

${ }^{120}$ Institute of Medicine, CARE Without Coverage: ToO LitTLE, ToO LATE (May 2002), available at http://www.iom.edu/Reports/2002/Care-Without-Coverage-Too-Little-TooLate.aspx.

${ }^{121}$ FAMILIES USA, Dying FOR COVERAGE: The DEADLy CONSEQUENCES OF BEING UNINSURED (June 2012), available at http://familiesusa.org/sites/default/files/product_documents/Dying-forCoverage.pdf.

12242 U.S.C. § 18091(2)(E).
} 
to provide coverage for employees. ${ }^{123}$ Rather than take a revolutionary approach to extending health care coverage that would have moved from an employer-based system to a single-payer system, the ACA took an incremental approach. In particular, the ACA embraced the idea that a full-time job should come with access to health insurance, and that a worker has an obligation to buy that insurance. The ACA did not force workers to buy their insurance on state or federal exchanges, or expand Medicare and Medicaid for everyone. ${ }^{124}$ The Act instead accepted as a given that most Americans receive health insurance coverage through their employers. At the same time, though, the government set minimum standards for the level of health coverage every American is entitled to, whether from an employer or not.

To meet the requirements set by the Act, insurance policies must, at a minimum, cover a broad array of “essential health benefits,” including emergency care, mental and behavioral health treatments, prescription drugs, and preventative services. ${ }^{125}$ Free contraception is just one of the mandatory elements of basic preventative care, along with free blood pressure screening, diet counseling, folic acid supplements for pregnant women, and flu shots. ${ }^{126}$ These services were considered so "essential” that insurance

${ }^{123}$ Individuals and employers who do not comply with the mandate must pay a "shared responsibility” tax. See The Individual Shared Responsibility Provision, IRS, http://www.irs.gov/Affordable-Care-Act/Individuals-and-Families/Individual-SharedResponsibility-Provision (last visited Dec. 5, 2014).

124 Indeed, the White House's Health Reform website attempts to debunk the myth that "[e]mployers will . . . stop offering insurance to their workers when the law is implemented." White House, Myths \& FACTS, Get THE FACT StRAight ON HEALTH REFORM, available at http://www.whitehouse.gov/healthreform/myths-and-facts.

${ }^{125}$ Essential Health Benefits, https://www.healthcare.gov/glossary/essential-health-benefits/. ${ }^{126}$ Preventative Health Services for Adults, https://www.healthcare.gov/preventive-carebenefits/\#part=2. 
companies were forbidden to charge any out-of-pocket costs for them, including copayments, coinsurance, or deductibles. ${ }^{127}$ Like the minimum wage, the federal government set the minimum floor of health benefits that workers are entitled to receive as a condition of their employment.

\section{Opting Out, v.2: The Hobby Lobby Decision}

\section{A. The Least Restrictive Means Is Taxing the Rest of Us}

Which brings us back to Hobby Lobby. The essential dispute in Hobby Lobby can be summarized succinctly. Hobby Lobby is a for-profit corporation that operates over 600 arts-and-crafts stores. ${ }^{128}$ The company has over 23,000 employees and earns over \$3 billion in annual revenue. ${ }^{129}$ Hobby Lobby’s stock is entirely owned by the Green family, devout Christians who argued that their faith opposes certain forms of contraception that they maintain are abortifacients. ${ }^{130}$ Under the ACA, group health plans, like the one offered by Hobby Lobby to its employees, are required to pay for "preventive care and screenings," including contraceptive methods approved by the FDA. ${ }^{131}$ In the name of Hobby Lobby, the Greens argued that the ACA's requirement that employer-funded group health plans pay for four particular types of contraceptives

${ }^{127}$ Id.

${ }^{128}$ Our Company, HoвBy LoBBy, http://www.hobbylobby.com/our_company/ (last visited Nov. 6, 2014).

${ }^{129}$ Hobby Lobby Stores, FORBES, http://www.forbes.com/companies/hobby-lobby-stores/ (last visited Nov. 6, 2014). The Supreme Court's decision cites the figures submitted to the Tenth Circuit, which appear to be out-of-date. See Hobby Lobby Stores, Inc. v. Sebelius, 723 F.3d 1114, 1122 (10th Cir. 2013) (noting that Hobby Lobby has 500 stores and 13,000 full-time employees).

130 Hobby Lobby, 134 S. Ct. 2751, 2765 (2014).

${ }^{131}$ Id. at 2754. 
violated the Religious Freedom Restoration Act (RFRA) ${ }^{132}$ by requiring them to "facilitate access" to these contraceptives, in violation of their religion. ${ }^{133}$ The Greens sought to enjoin the so-called contraceptive mandate so that Hobby Lobby would not have to provide coverage for those contraceptives to its employees. ${ }^{134}$

\section{i. Smith and the History of the Religious Freedom Restoration Act}

In its decision, the Hobby Lobby majority purported to conduct a simple exercise in statutory interpretation to determine the meaning and scope of RFRA. A nearlyunanimous Congress ${ }^{135}$ passed RFRA in 1993 in response to the Supreme Court's decision in Employment Division v. Smith. ${ }^{136}$ Smith was controversial from the start; Justice Scalia, writing for a bare majority, ${ }^{137}$ found that there was no need to apply the Court's balancing test as established in Sherbert v. Verner, "whereby governmental actions that substantially burden a religious practice must be justified by a 'compelling governmental interest." " 138 Instead, the Court determined that in the case of two members of the Native American Church who used peyote as part of their spiritual

13242 U.S.C. $\S 2000 b b-1$.

133 Hobby Lobby, 134 S. Ct. at 2755.

${ }^{134}$ Mardel Christian and Educational Supply, owned by one of the Greens’ sons, was an additional plaintiff to Hobby Lobby's lawsuit. At the Supreme Court, Hobby Lobby and Mardel's suit was consolidated with that of another similar for-profit corporation, Conestoga Wood Specialties, making similar claims.

135 The final vote in the Senate was 97 to 3. See https://www.govtrack.us/congress/votes/1031993/s331. Because the vote in the House was by voice, no record of individual votes was made, but there were 170 cosponsors. See https:/www.govtrack.us/congress/bills/103/hr1308.

136494 U.S. 872 (1990).

${ }^{137}$ Chief Justice Rehnquist, and Justices White, Stevens, and Kennedy joined Justice Scalia’s opinion; Justice O’Connor filed an opinion concurring in the judgment; and Justices Brennan, Marshall and Blackmun dissented.

${ }^{138}$ Smith, 494 U.S. at 873. 
practice, the government's interest in ensuring “across-the-board criminal prohibition on a particular form of conduct” overrode any religious objections. ${ }^{139}$

A holding to the contrary would create an extraordinary right to ignore generally applicable laws that are not supported by 'compelling governmental interest' on the basis of religious belief. Nor could such a right be limited to situations in which the conduct prohibited is 'central' to the individual's religion, since that would enmesh judges in an impermissible inquiry into the centrality of particular beliefs or practices to a faith. ${ }^{140}$

As a result, Smith held that the Free Exercise Clause of the Constitution:

does not relieve an individual of the obligation to comply with a law that incidentally forbids (or requires) the performance of an act that his religious belief requires (or forbids) if the law is not specifically directed to religious practice and is otherwise constitutional as applied to those who engage in the specified act for nonreligious reasons. ${ }^{141}$

A “formidable group" of 68 civil and religious liberties organizations banded together to persuade Congress to repudiate Smith, which they feared would enable the government to "interfere" with their religious practices. ${ }^{142}$ The Religious Freedom Restoration Act proclaimed that “Government shall not substantially burden a person's exercise of religion even if the burden results from a rule of general applicability,” unless "it demonstrates that application of the burden to the person - (1) is in furtherance of a compelling governmental interest; and (2) is the least restrictive means of furthering that compelling governmental interest.”"143 The statute’s stated purpose was to overturn Smith

\footnotetext{
${ }^{139} \mathrm{Id}$

${ }^{140} \mathrm{Id}$.

${ }^{141} \mathrm{Id}$.

142 Gustav Niebuhr, Forming Earthly Alliances to Defend God's Kingdom, N.Y. TIMES, Aug. 28, 1994; Peter Steinfels, Beliefs, N.Y. Times, Feb. 29, 1992.

143 Religious Freedom Restoration Act of 1993, 42 U.S.C. § 2000bb-1.
} 
and "restore the compelling interest test as set forth in Sherbert $v$. Verner ... and Wisconsin v. Yoder ... and to guarantee its application in all cases where free exercise of religion is substantially burdened." 144

In those previous cases, the clash was - as in Smith - between the government's interest in enforcing secular laws and a human being's interest in adhering to a particular religious practice or belief. That is, the Court considered the government's interest in denying Adell Sherbert's unemployment benefits when she refused to work on her Sabbath, ${ }^{145}$ or the State’s interest in requiring Jonas Yoder's children to attend high school contrary to his Amish beliefs. ${ }^{146}$ These cases did not deal with assertions by forprofit corporations that they held religious beliefs. And in cases like Lee where employers made such arguments, the courts held that the rights of the employer were outweighed by the government's interest in ensuring that employees got the statutory benefits to which secular laws entitled them. RFRA itself made no specific mention of the exercise of religion by a corporation, only by a "person” or "persons.", 147

\section{ii. Corporate Personhood Under RFRA}

Notwithstanding this history, the Hobby Lobby majority determined that, “[n]othing in RFRA suggests a [C]ongressional intent to depart from the Dictionary Act

\footnotetext{
${ }^{144} I d$. at (b)(1). The Supreme Court likewise characterized the scope of RFRA as "expressly adopt[ing] the compelling interest test of Sherbert $v$. Verner . . . and Wisconsin v. Yoder" in Gonzales v. O Centro Espirita Beneficente Uniao do Vegetal, 546 U.S. 418, 420 (2006).

145 Sherbert v. Verner, 374 U.S. 398 (1963).

${ }^{146}$ Wisconsin v. Yoder, 406 U.S. 205 (1972).

14742 U.S.C. § 2000bb-1.
} 
definition of 'person,' which 'include[s] corporations, . . . as well as individuals.'”148 Thus, Hobby Lobby and other for-profit companies had a right to bring RFRA claims. This article will not focus on that holding, which is a subject worthy of an article unto itself and has already been the subject of scholarly interest. ${ }^{149}$ I will sketch out some thoughts on the tension in the Court's reasoning related to corporate law below, but for now, it suffices to note that the majority held that for-profit corporations could make the same claims under RFRA as could a human being or a non-profit corporation dedicated explicitly to religious purposes, like a church, thereby "protect[ing] the religious liberty of the humans who own and control those companies."

\section{iii. The Majority's Application of the RFRA Balancing Test}

As a result, the Court proceeded to conduct the balancing test required by the statute: "we must next ask whether the HHS contraceptive mandate 'substantially burden[s]' the exercise of religion. We have little trouble concluding that it does.”151 The majority started by essentially taking for granted that the religious beliefs of the Greens, the family that owns all of Hobby Lobby's stock, were burdened by the

${ }^{148}$ Hobby Lobby, 134 S. Ct. 2751, 2755 (2014); see also id. at 2794 (Ginsburg, J., dissenting) ("Until this litigation, no decision of this Court recognized a for-profit corporation's qualification for a religious exemption from a generally applicable law, whether under the Free Exercise Clause or RFRA. The absence of such precedent is just what one would expect, for the exercise of religion is characteristic of natural persons, not artificial legal entities.”) (citations omitted). ${ }^{149}$ See, e.g., Malcolm J. Harkins, The Uneasy Relationship of Hobby Lobby, Conestoga Wood, the Affordable Care Act and the Corporate Person: How a Historical Myth Continues to Bedevil the Legal System, 7 St. Louis Univ. J. HeAlth L. \& PoL'Y 201 (2014); Alan J. Meese \& Nathan B. Oman, Hobby Lobby, Corporate Law, and the Theory of the Firm: Why For-Profit Corporations are RFRA Persons, 127 HARV. L. REV. F. 273 (2014); Spencer Churchill, Whose Religion Matters in Corporate RFRA Claims after Burwell v. Hobby Lobby Stores?, 38 HARV. J. L. \& PUB. POL'Y 1 (2014).

${ }^{150}$ Hobby Lobby, 134 S. Ct. at 2768.

${ }^{151} I d$. (citations omitted). 
requirement to offer four specific contraceptives as part of the insurance coverage that Hobby Lobby offered to employees. Indeed, the Court refused to engage in any inquiry as to whether there was any real burden: "it is not for us to say that their religious beliefs are mistaken or insubstantial. Instead, our 'narrow function ... in this context is to determine' whether the line drawn reflects 'an honest conviction,' and there is no dispute that it does.”152 That Hobby Lobby had in fact covered two of the objected-to contraceptives in its plan before initiating the lawsuit was never mentioned by the Court. ${ }^{153}$ Nor did the Court quibble with the Greens’ assertion that the contraceptives were abortifacients, even though the Federal government does not classify them as such. $^{154}$

Having assumed that "the HHS contraceptive mandate imposes a substantial burden on the exercise of religion,” the majority then determined that HHS had not

${ }^{152}$ Id. at 2779 (citing Thomas v. Review Bd. of Indiana Emp't Sec. Div., 450 U.S. 707, 716 (1981)). The lack of inquiry into the first prong of the RFRA test is consistent with the general approach courts have taken. See generally Jonathan C. Lipson, On Balance: Religious Liberty and Third-Party Harms, 84 MinN. L. REV 589 (2002) (discussing courts' reluctance to determine a precise definition of religious exercise, and to balance competing harms from that exercise with the secular rights of other actors). See also MARCI A. HAMILTON, GOD VS. THE GAVEL: RELIGION AND THE RULE OF LAW 7 (2005) ("Religious entities have the capacity for great good and great evil, and society is not duty bound by any constitutional right to let them avoid duly enacted laws, especially where their actions can harm others. To say that religious liberty must encompass the right to harm others is to turn the First Amendment on its head."). ${ }^{153}$ See Katie Sanders, Did Hobby Lobby Once Provide the Birth Control Coverage It Sued the Obama Administration Over? POLITIFACT (July 1, 2014), available at http://www.politifact.com/punditfact/statements/2014/jul/01/sally-kohn/did-hobby-lobby-onceprovide-birth-control-coverag/ (citing Hobby Lobby's original complaint, par. 55, available at http://www.becketfund.org/wp-content/uploads/2012/09/Hobby-Lobby-Complaintstamped.pdf.).

${ }^{154}$ See Hobby Lobby, 134 S. Ct. at 2763, n.7 ("The owners of the companies involved in these cases and others who believe that life begins at conception regard these four methods as causing abortions, but federal regulations, which define pregnancy as beginning at implantation . . . do not so classify them.”). 
shown that the contraceptive mandate "(1) is in furtherance of a compelling government interest; and (2) is the least restrictive means of furthering that compelling government interest,” as required by RFRA. ${ }^{155}$ The Court found that exemptions already present in the law undermined the government's claim that the mandate served such a compelling interest. But those exemptions covered only employees in "grandfathered" plans and those who worked for companies with fewer than 50 employees. ${ }^{156}$ It is not uncommon for federal mandates to exempt smaller employers - as the dissent notes, ${ }^{157}$ the Family and Medical Leave Act, ${ }^{158}$ Age Discrimination in Employment Act, ${ }^{159}$ Americans with Disabilities Act, ${ }^{160}$ and Title VII ${ }^{161}$ all contain similar provisions, even though each statute inarguably promotes fundamental government interests. Likewise, the ACA's grandfathering exemption merely provides for a temporary phasing-in period, and it was not disputed that the number of employees in grandfathered plans will continue to decline over time, as it had from 2011 to $2013 .{ }^{162}$ Ultimately, though, the majority found it "unnecessary to adjudicate th[e] issue" of whether the government's interest in extending the minimum essential coverage to all Americans was "compelling." 163 They concluded

${ }^{155}$ Id. at 2779 (citing 42 U.S.C. § 2000bb-1(b)).

${ }^{156}$ Id. at 2780.

${ }^{157}$ Id. at 2800-01 (Ginsburg, J. dissenting).

15829 U.S.C. § 2611(2)(B)(ii) (exempting workplaces with less than 50 employees).

15929 U.S.C. § 630(b) (exempting workplaces with less than 50 employees before June 30, 1968, and 20 employees thereafter).

16042 U.S.C. § 1211(5)(A) (exempting workplaces with less than 25 employees for the first two years following the effective date of the statute, and 15 employees thereafter).

16142 U.S.C. § 2000e(b) (exempting workplaces with less than 15 employees).

162 Kaiser Family Foundation, Employer Health Benefits 2013 ANNUAL SuRVey 221 2013), available at http://kaiserhealthnews.files.wordpress.com/2013/11/8465-employer-healthbenefits-20131.pdf.

${ }^{163}$ Hobby Lobby, 134 S. Ct. at 2780. 
that even if it was, the ACA did not use the "least restrictive means" of achieving the government's interest, and thus failed under RFRA. ${ }^{164}$

The Court posited that a mandate was not the least restrictive method of providing access to contraception because "[t]he most straightforward way of doing this would be for the Government to assume the cost of providing the four contraceptives at issue to any women who are unable to obtain them under their health-insurance policies due to their employers' religious objections.” ${ }^{165}$ Essentially, the majority determined that a corporation's religious objection to providing its employees with the minimum benefits guaranteed under the law can override any rights of the employee, so long as "the government, i.e., the general public, can pick up the tab,” to quote Justice Ginsburg’s dissent. ${ }^{166}$ But Congress established certain minimum guarantees precisely to avoid those kinds of corporate externalities and to give every worker a right to minimum essential coverage. As the dissent also pointed out, "Safety net programs ... are not designed to absorb the unmet needs of . . . insured individuals.”167

In other words, the ACA was intended to limit the ability of less responsible employers to shift the costs of their workers' health costs onto others, including the worker's spouse's employer, hospitals (for emergency care), and taxpayers generally (because the government is the ultimate backstop guarantor of care for the uninsured). Large companies had been criticized for providing only "high expense and bare-bones

${ }^{164} \mathrm{Id}$.

${ }^{165} \mathrm{Id}$. (emphasis added).

${ }^{166}$ Id. at 2787 (Ginsburg, J., dissenting).

${ }^{167}$ Id. at 2802 (Ginsburg, J., dissenting). 
coverage” to employees, and attempting to avoid paying premiums by hiring more parttime workers and “discouraging unhealthy people” from taking jobs. ${ }^{168}$ As of 2001, employees of large firms, those with 500 or more employees, were increasingly likely to be uninsured: more than 1 in 4 uninsured individuals worked in or had a family member working for a large employer. ${ }^{169}$ Those 9.6 million Americans represented a third of the total working uninsured - a 30\% increase from $1987 .{ }^{170}$ In the face of these trends, several states, including California and Washington, attempted to enact legislation requiring big companies "to either provide affordable health insurance to their workers or pay into a state insurance pool." ${ }^{171}$

But these concerns were not relevant to the Hobby Lobby majority. ${ }^{172}$ They placed no weight on employees’ own religious beliefs or practices - indeed, they

${ }^{168}$ See, e.g., Michael Barbaro \& Reed Abelson, A Health Plan for Wal-Mart: Less Stinginess, N.Y. TIMES, Nov. 13, 2007, available at http://www.nytimes.com/2007/11/13/business/13walmart.html.

${ }^{169}$ SherRy Glied, ET AL., COMmONWEALth Fund, The Growing SHARE OF UNinSURED WORKERS EMPLOYED BY LARGE FIRMS 2 (Oct. 2003), available at http://www.commonwealthfund.org/ /media/files/publications/fund-report/2003/oct/thegrowing-share-of-uninsured-workers-employed-by-large-firms/glied_largefirms_672-pdf. ${ }^{170} I d$.

${ }^{171}$ Reed Abelson, States Are Battling Against Wal-Mart Over Health Care, N.Y. Times, Nov. 1, 2004, available at http://www.nytimes.com/2004/11/01/business/01health.html.

${ }^{172}$ Unlike the majority, I acknowledge that there is a clash of interests. There is no doubt that when the government imposes a system of secular guarantees of minimum economic support that come with a job, it is likely in some respects to intrude on the beliefs of employers. But that risk is tempered by two important realities. First, the system must be secular in the sense of applying neutrally to all employers, and not be intended to benefit or harm those who hold certain religious beliefs. Second, the system will be the product of legislative decisions made by elected representatives, who will be influenced by those with religious beliefs. By reading RFRA to give little weight to the interests of society in extending minimum guarantees of economic dignity, the Hobby Lobby majority subjects workers to a different kind of sovereign - the managers of the corporations which employ them. Because many large corporations employ more workers than live in sizable municipalities, the freedom of the many will be subject to the decisions of a group of corporate managers who workers have no role in selecting. The 
dismissed any concerns about the burden placed on "third parties" in a footnote. ${ }^{173}$ They also asserted that there was no burden on Hobby Lobby employees because "the Government can readily arrange for other methods of providing contraceptives, without cost sharing, to employees who are unable to obtain them under their health-insurance plans due to their employers' religious objections.” ${ }^{174}$ The majority referred to the government's exemption for any non-profit organization that "holds itself out as a religious organization” and “opposes providing coverage for some or all of any contraceptive services required to be covered . . . on account of religious objections.”175 For those organizations, the insurance issuer must, at its own expense, "provide separate payments for contraceptive services for plan participants without imposing any costsharing requirements on the eligible organization, its insurance plan, or its employee beneficiaries.” ${ }^{176}$

"Hobson's choice" of giving up a job in order to have the full measure of economic rights Congress says should come with a job has a bitter irony.

${ }^{173}$ Hobby Lobby, 134 S. Ct. at 2781 n.37. Professor Lipson suggested in a prescient article that harm to third parties should instead be the primary consideration in determining whether the State's burden on religious exercise is appropriate: "where religious exercise harms third parties . . the scale should be evenly set. Religious actors should not enjoy the presumptive force of strict scrutiny, however derived. Courts should, in such conte[x]ts, do the hard work of determining whether the conduct really is a religious exercise and if so, whether it is of sufficient importance to warrant an exemption.” Lipson, supra note 152, at 671. See also Frederick Mark Gedicks \& Andrew Koppelman, Invisible Women: Why an Exemption for Hobby Lobby Would Violate the Establishment Clause, 67 VAND. L. REV. 51, 54 (2014) (arguing that "the Establishment Claus does prohibit RFRA's application when - as with the exemption sought by Hobby Lobby - a particular exemption would shift the costs of the accommodated religious practice to identifiable and discrete third parties in the for-profit workplace"). ${ }^{174} I d$.

${ }^{175}$ Id. at 2763 (citing 45 C.F.R. § 147.131(b)).

${ }^{176} \mathrm{Id}$. The accommodation itself is also controversial. See Little Sisters of the Poor Home for the Aged v. Sebelius, 6 F. Supp. 3d 1225 (D. Colo. 2013), injunction granted pending appeal, 
But the accommodation that the majority claimed could step in to provide the required contraceptives was not designed to cover employees of for-profit retail establishments; it was meant to exempt only the small number of employees who work for religious non-profits. According to the Bureau of Labor Statistics, $0.05 \%$ of Americans workers are classified as "religious workers," including clergy, directors of religious activities, religious school teachers, and other related roles. ${ }^{177}$ The entire nonprofit sector employs 11 million workers - an important segment of the workforce, to be sure, but only a fraction of the nearly 120 million employees who work in the private sector. ${ }^{178}$ By contrast, retail salespersons and cashiers - the bulk of Hobby Lobby’s employees - comprised the largest segment of the American workforce. ${ }^{179}$

Although the majority attempted to limit their holding only to "closely held corporations," ${ }^{180}$ those companies are no small segment of the workforce. By some

134 S. Ct. 1022 (2014); see also Hobby Lobby, Oral Arg’t Tr. 86-87 (“Mr. Clement: We haven't been offered that accommodation, so we haven't had to decide what kind of objection, if any, we would make to that.").

${ }^{177}$ BuREAU OF LabOr STATistics, May 2013 OCCUPATIONAL EMPLOYMENT STATistics, available at http://www.bls.gov/oes/\#data.

${ }^{178}$ Bureau of Labor Statistics, ReSEARCh Data on the NonPRofit Sector: 2012 AnNuAL AvERAGES, available at http://www.bls.gov/bdm/nonprofits/nonprofits.htm (Table B-1); BUREAU OF LABOR STATISTICS, EMPLOYEES ON NONFARM PAYROLLS BY INDUSTRY SECTOR AND SELECTED INDUSTRY DETAIL: OCT. 2014, available at http://www.bls.gov/news.release/empsit.t17.htm.

${ }^{179} I d$. The retail trade as a whole employs nearly 15.5 million people, more than half of whom are salespeople. BUREAU OF LABOR STATISTICS, supra note 177.

${ }^{180}$ Hobby Lobby, 134 S. Ct. at 2774 ("These cases, however, do not involve publicly traded corporations, and it seems unlikely that the sort of corporate giants to which HHS refers will often assert RFRA claims."). But, as other commentators have noted, this prediction does not actually create a limiting factor. See, e.g., Elizabeth Sepper, Gendering Corporate Conscience, 39 HARV. J.L. \& GENDER (Forthcoming 2014), at 34 ("Yet the Hobby Lobby Court struggled to articulate any principle that might contain corporate conscience.... The Court could offer only pragmatic predictions, rather than principled reasons, for why its holding would not equally 
estimates, close corporations account for up to two-thirds of private sector employment. ${ }^{181}$ And, to quote the dissent, ““[c]losely held’ is not synonymous with ‘small.”,'182 According to Forbes, 221 privately-owned companies earn revenues of at least \$2 billion, ${ }^{183}$ including Cargill (\$134.9 billion, 145,000 employees worldwide ${ }^{184}$ ), Koch Industries (\$115 billion, 100,000 employees worldwide, 60,000 in the U.S. ${ }^{185}$ ), and Dell ( $\$ 57.2$ billion, 110,000 employees worldwide ${ }^{186}$ ). Thus, what had been created as a minor exception for church employees broadened into a much larger potential threat to the law, and specifically to the minimum essential coverage guaranteed to each worker by the ACA. ${ }^{187}$

Finally, the majority rejected the possibility that its holding would "lead to a flood of religious objections" to other procedures, by noting that "[o]ther coverage

extend to public corporations.”). Indeed, supporters of broader exemptions for corporations asserting religious beliefs have cited this part of the holding as evidence in their favor. See, e.g., Lyman Johnson, et al., Comments on the HHS' Flawed Post-Hobby Lobby Rules, at 2 (Oct. 20, 2014), available at http://papers.ssrn.com/sol3/papers.cfm?abstract_id=2512860 ("although the three companies in that litigation were 'closely-held,' the Court's reasoning decidedly was not limited to such companies.”).

${ }^{181}$ John Asker, et al., Corporate Investment and Stock Market Listing: A Puzzle?, at 5, REv. Fin. STUDIES (forthcoming), available at http://papers.ssrn.com/sol3/papers.cfm?abstract_id=1603484 (estimating that private U.S. firms accounted for $68.7 \%$ of private-sector employment in 2010). But see Venky Nagar, et al., Governance Problems in Closely-Held Corporations, 46 J. FIN. \& QUANT. ANALYSIS 943 (2011) (estimating that closely held corporations employ 52\% of the labor force, based on 2004 data). ${ }^{182}$ Hobby Lobby, 134 S. Ct. at 2979 n.19 (Ginsburg, J., dissenting).

${ }^{183}$ America's Largest Private Companies 2014, ForBES (Nov. 5, 2014), available at http://www.forbes.com/sites/andreamurphy/2014/11/05/americas-largest-private-companies2014/.

${ }^{184}$ Cargill at a Glance, CARGILL, http://www.cargill.com/company/glance/ (last visited Nov. 7, 2014).

${ }^{185}$ Koch Overview (Aug. 2014), KocH InDUSTRIES, http://www.kochind.com/files/kochfacts.pdf (last visited Nov. 7, 2014).

${ }^{186}$ Dell's Next Chapter (Nov. 1, 2013), DeLL, http://en.community.dell.com/dellblogs/direct2dell/b/direct2dell/archive/2013/11/01/tbd (last visited Nov. 7, 2014).

${ }^{187}$ Sherbert v. Verner, 374 U.S. 398 (1963). 
requirements ... may be supported by different interests ... and may involve different arguments about the least restrictive means of providing them." ${ }^{188}$ But by its own logic, as the dissent articulates, there is no "stopping point to the 'let the government pay' alternative.” 189 Neither the majority nor the dissent questioned that Hobby Lobby had "sincere religious beliefs" that would be violated by paying into an insurance fund that could then be used to pay for certain contraceptives. But the list of possible legitimate religious objections to medical procedures is almost endless. And employers have already protested paying for any contraceptives, not just the four supposed abortifacients at issue in Hobby Lobby. ${ }^{190}$

Hobby Lobby thus paves the way for a Jehovah's Witness employer to object to paying for insurance that covers blood transfusions, for example. ${ }^{191}$ Jewish and Muslim employers might object to covering stays in hospitals that do not adhere to strict Kosher or Halal dietary regimes. Hindu employers might object to covering implants made with bovine collagen. ${ }^{192}$ By parity of reasoning, when any sincerely held religious belief conflicts with a minimum benefit guaranteed by the Affordable Care Act, the benefit -

${ }^{188}$ Hobby Lobby, 134 S. Ct. at 2783 (emphasis added).

${ }^{189} \mathrm{Id}$. at 2802 (Ginsburg, J., dissenting).

${ }^{190}$ See, e.g., Little Sisters of the Poor Home for the Aged v. Sebelius, 6 F. Supp. 3d 1225 (D. Colo. 2013), injunction granted pending appeal, 134 S. Ct. 1022 (2014).

${ }^{191}$ See, e.g., Karen L. Diaz, Refusal of Medical Treatment Based on Religious Beliefs: Jehovah's Witness Parents, 16 J. ConTEMP. Legal Issues 85 (2007) (noting that Jehovah's Witnesses object to blood transfusions on religious grounds, but that courts have uniformly authorized state intervention to protect their minor children in the event such intervention is medically necessary).

${ }^{192}$ See, e.g., Catherine Easterbrook \& Guy Maddern, Porcine and Bovine Surgical Products Jewish, Muslim, and Hindu Perspectives, 143 ARCHIVES SuRGERY 366 (2008) (finding that Hindu religious leaders did not accept the use of bovine surgical implants). 
and the employee's right to receive it - must yield. The majority's only argument in

response was that other employers have not yet brought RFRA claims of this type. ${ }^{193}$

\section{B. The Broader Implications of Hobby Lobby and Its Effects on Worker Freedom and Society's Ability to Extend the Social Safety Net}

The implications of Hobby Lobby cannot easily be confined to health insurance.

In terms of the religious interests at stake, there is no fundamental difference between healthcare coverage and other forms of compensation, like cash wages. RFRA applies, by its express terms, to "all Federal law, and the implementation of that law, whether statutory or otherwise, and whether adopted before or after November 16, 1993.”"194 Because RFRA acts as a gloss on the Fair Labor Standards Act, say, just as much as the Affordable Care Act, a legitimate religious objection to paying minimum wage might also prevail, or an employer like Hobby Lobby could attempt to condition the payment of wages, minimum or not, on an agreement by the worker not to spend any of those wages in ways that the employer finds religiously objectionable. Although the FLSA abolished scrip and required employers to pay workers in freely usable U.S. currency, under the reasoning of Hobby Lobby, the employer's religious beliefs could be compromised if an employee used Hobby Lobby wages to buy an IUD. ${ }^{195}$ After all, like the minimum essential coverage under the ACA, the wages paid to an employee for the employee's

\footnotetext{
193 Hobby Lobby, 134 S. Ct. at 2783.

19442 U.S.C. $\$ 2000$ bb-3(a).

${ }^{195}$ It is worth noting that even though paying in company scrip is no longer legal in the United States, the idea has not disappeared from corporate practice. Walmart's Mexican subsidiary attempted to pay workers in vouchers redeemable only at company stores until the practice was found unconstitutional by Mexico’s Supreme Court. See Mexican Court Rules Against WalMart, N.Y. TimEs (Sept. 5, 2008), available at http://www.nytimes.com/2008/09/06/world/americas/06mexico.html.
} 
labor comes out of the employer's treasury. If it burdens an employer's religious freedom for its employee to use the full range of coverage that her doctor says is medically necessary, then so too would it burden the employer to have the wages it paid used by its employees for products and services to which the employer objects. By treating the employer as having a substantial, conscience-burdening role simply because it accords its workers the statutorily mandated minimum level of economic support that workers are supposed to be able to use according to their own choices, Hobby Lobby empowers employers to claim that strings should be attached to wages themselves. ${ }^{196}$ Moreover, the reasoning of Hobby Lobby also has implications for taxes, because RFRA acts as an override on all federal law, including the Internal Revenue Code. ${ }^{197}$ If Hobby Lobby is burdened by having its funds pay for IUDs, and the government cannot act in the "least restrictive manner" unless it shifts the costs of those contraceptives to other taxpayers, then Hobby Lobby should be able to make a claim that its tax bill should be reduced by the share of the federal budget that goes to provide those contraceptives. If the answer to applying the reasoning of Hobby Lobby to these other contexts is that its

${ }^{196}$ Nor am I the first to note the logical implications of Hobby Lobby for cash wages: the federal District Court in O'Brien v. U.S. Dept. of Health and Human Services made a similar point when considering a case under RFRA before Hobby Lobby: "In this case, however, the burden on plaintiffs is even more remote; the health care plan will offend plaintiffs' religious beliefs only if an OIH employee (or covered family member) makes an independent decision to use the plan to cover counseling related to or the purchase of contraceptives. Already, OIH and Frank O’Brien pay salaries to their employees - money the employees may use to purchase contraceptives or to contribute to a religious organization. By comparison, the contribution to a health care plan has no more than a de minimus impact on the plaintiff's religious beliefs than paying salaries and other benefits to employees.” 894 F. Supp. 2d 1149, 1160 (E.D. Mo. 2012).

19742 U.S.C. § 2000bb-3(a); Adams v. Comm'r, 170 F.3d 173 (3d Cir. 1999), cert. denied, 528 U.S. 1117 (2000) (noting that the Commissioner did not dispute the applicability of RFRA in a case involving a religious objection to paying federal income taxes). 
application would lead to absurd results, that is a confession that the reasoning itself is not sound, and cannot be applied in like cases to yield sensible results. ${ }^{198}$

Requiring the federal government to create a system of patchwork opt-outs to an important universal health coverage bill is not a small thing. According to one study of our "kludgeocracy" - that is, a system in which patches and workarounds are used in place of a comprehensive fix - complexity in government programs costs hundreds of billions a year, leads to frequent failures, like the response to Hurricane Katrina, and undermines democracy by obscuring lines of accountability. ${ }^{199}$

This last factor is particularly relevant in the health insurance context; many Americans “mistake as 'private’ market structures those programs that are in fact pervasively shaped by government.”200 Hence the oxymoronic complaint at a 2009 political rally: “keep your government hands off my Medicare.”201 No patriotic American should be happy about this lack of clarity: enabling employers to shift the cost of healthcare onto other taxpayers, yet claim credit for providing for employees,

\footnotetext{
198 The same analysis applies to bankruptcy laws, which can intersect with religious claims in multiple ways. See Jonathan C. Lipson, When Churches Fail: The Diocesan Debtor Dilemmas, 79 S. CAL. L. REV. 363 (2006) (discussing the "doctrinal dilemma” facing bankruptcy courts when considering claims by Catholic dioceses filing cases under Chapter 11 of the U.S. Bankruptcy Code because liquidating Church assets may burden their religious exercise); Lipson, supra note 152 (discussing the Ninth Circuit's initial decision in Thomas v. Anchorage Equal Rights Comm'n precluding a bankruptcy trustee from avoiding and recovering insolvent religious debtors' contributions to their church on RFRA grounds).

199 Steven M. Teles, Kludgeocracy: The American Way of Policy, NEW AmERICA Foundation (Dec. 2012), http://newamerica.net/sites/newamerica.net/files/policydocs/Teles_Steven_Kludgeocracy_NAF_ Dec2012.pdf (last visited Nov. 7, 2014).

${ }^{200}$ Id. at 3 (citing SuZAnNe MetTler, The Submerged StATE (2011)).

${ }^{201}$ See Philip Rucker, Sen. DeMint of S.C. Is Voice of Opposition to Health-Care Reform, WASHINGTON POST (July 28, 2009).
} 
"facilitates the myth of independence and rugged individualism upon which modern conservatism is based, while also creating the impression that only other, less deserving people, are able to draw upon government largesse.”202 At the same time, though, “[p]ursuing public goals through regulation and litigation doesn't eliminate the costs of government, but it does make it hard for citizens to see the costs of public action . . .."203 Complexity also drives up the cost of healthcare overall, in a system that is already the most expensive in the world, yet one of the worst in terms of access, efficiency, and equity, and only middling in terms of quality. ${ }^{204}$

Nor is it a small thing to suggest that non-objecting taxpayers should fund any social priority that is opposed by a for-profit corporation on religious grounds. Not only will it become more expensive to implement social welfare programs, which now have to be designed to allow for taxpayer-funded carve-outs, with all of the complex and expensive administrative work-arounds that such exemptions entail. It will also generate arguments against the expansion and adoption of such programs in the first instance. Opponents will be correct to note that adherence to RFRA - as articulated in Hobby Lobby - will require expensive accommodations that add to the cost of any proposed program, perhaps beyond what the government can afford. ${ }^{205}$

\footnotetext{
202 Teles, supra note 199, at 4.

${ }^{203}$ Id.

${ }^{204}$ Karen Davis, et al., Mirror, Mirror on the Wall, 2014 Update: How the U.S. Health Care System Compares Internationally, THE COMMONWEALTH FUND (2014), available at http://www.commonwealthfund.org/publications/fund-reports/2014/jun/mirror-mirror.

${ }^{205}$ As Professor Sepper notes, providing exemptions operates as a "substantial tax subsidy" to employers like Hobby Lobby, which ultimately leads to an "open-ended increase in the cost to the government.” Elizabeth Sepper, Gendering Corporate Conscience, 39 HARV. J.L. \& GENDER
} 


\section{Are We Doomed to Repeat the Past?}

Stemming the growth of the social safety net while allowing corporate paternalism to thrive risks undermining the freedoms guaranteed to workers by laws enacted over the past century. And the confluence of these risk factors is ill-timed. Unions, which formed to protect laborers in the late $19^{\text {th }}$ and early $20^{\text {th }}$ century, are now on the decline. ${ }^{206}$ In 1983, $20 \%$ of U.S. workers belonged to unions; in 2013, that figure was $11 \%{ }^{207}$ And, just as in Henry Ford's time, the individuals most likely to be affected by an employer's moral restrictions are those with the fewest options for new employment. For example, Hobby Lobby employees enjoy higher-than-average wages: \$14 per hour for full-time workers, and $\$ 9.50$ for part-time workers, compared to the federal minimum wage of $\$ 7.25 .^{208}$ Given its generosity relative to the norm, it is not surprising that Hobby Lobby

(Forthcoming 2014), at 30 (quoting Solicitor General Verrilli, Transcript of Oral Argument at 66, Burwell v. Hobby Lobby, 134 S. Ct. 2751 (2014) (Nos. 13-354, 13-356)).

${ }^{206}$ Given the particular involvement of organized labor in promoting employer-based health insurance, this decline is particularly relevant in this context. See Helms, supra note 108, at 1112. Incidentally, on the same day that Hobby Lobby was decided, the Supreme Court also issued its decision in Harris v. Quinn, 134 S. Ct. 2618 (2014), which further limited union growth by holding that the provisions of Illinois' Public Labor Relations Act requiring home-care personal assistants to pay union fees violated the First Amendment. Some commentators noted that notwithstanding the lack of public recognition of the case, it dealt a "devastating blow" to public unions. See, e.g., Sam Baker \& Emma Roller, The Supreme Court Just Dealt a Devastating Blow to Public Unions, National Journal, June 30, 2014, http://www.nationaljournal.com/politics/the-supreme-court-just-dealt-a-devastating-blow-topublic-unions-20140630.

${ }^{207}$ Bureau of Labor Statistics, Union MEMBERs Summary 2013, http://www.bls.gov/news.release/union2.nr0.htm.

${ }^{208}$ Leonardo Blair, Hobby Lobby Raises Minimum Wage to \$14 for Full-Time Employees, CHRISTIAN POsT, Apr. 18, 2013, http://www.christianpost.com/news/hobby-lobby-raisesminimum-wage-to-14-for-full-time-employees-94233/. 
boasts about its employee retention rate. ${ }^{209}$ But put that in context: \$14 per hour, assuming a 40 hour week, 50 weeks a year, equates to $\$ 28,000$ a year before taxes. ${ }^{210}$ For a family of five, that sum is just about the poverty line. ${ }^{211}$

\section{i. Good Jobs Are Hard to Find, or, in Other Words, Escaping Hobby Lobby Is Not so Easy}

Although the lingering effects of the Great Recession seem to be wearing off, most workers with jobs have substantial reasons to hesitate before leaving them. A plurality of American voters still cite unemployment and job creation as their biggest concerns. ${ }^{212}$ Only three in ten Americans think now is a good time to find a quality job. ${ }^{213}$ And these concerns reflect economic reality: according to the Department of Labor, even though the overall unemployment rate is down, the number of long-term unemployed is still high: 3

${ }^{209}$ See Angelo Young, The Same Religious Conviction that Has Hobby Lobby Challenging Obamacare Is also Why Its Full Timers Start at \$14 an Hour with Evenings (and Thanksgiving) Off, INTERNATIONAL Business TiMES, Nov. 13, 2013, http://www.ibtimes.com/same-religiousconviction-has-hobby-lobby-challenging-obamacare-also-why-its-full-timers-start-14.

${ }^{210}$ Contrary to the common perception, the poor do pay taxes; according to one estimate, accounting for all federal, state, and local taxes, "the bottom fifth of households pays about 16 percent of their incomes in taxes, on average.” Chuck Marr \& Chye-Ching Huang, Misconceptions and Realities About Who Pays Taxes, Center On BUdget \& POLICy Priorities (Sept. 17, 2012), http://www.cbpp.org/cms/?fa=view\&id=3505\#_ftn8.

${ }^{211}$ The federal poverty guideline is $\$ 27,910$ for a family of five. U.S. DEPT. OF HEATH \& HUMAN SERVICES, 2014 POVERTY GUIDELINES, http://aspe.hhs.gov/poverty/14poverty.cfm (last visited Sept. 18, 2014).

${ }^{212}$ See, e.g., Susan Page, et al., Poll: High Anxiety, Low Expectations as Election Nears, USA TODAY, Oct. 30, 2014, available at http://www.usatoday.com/story/news/politics/elections/2014/10/30/usa-today-poll-high-anxietylow-expectations/18118403/ (discussing results of poll of 1,210 adults taken Oct. 23-26 by Princeton Survey Research).

${ }^{213}$ Andrew Dugan, In U.S., 31\% Say Now Is a Good Time to Find a Quality Job, GALLUP, available at http://www.gallup.com/poll/178775/say-good-time-find-quality-job.aspx (last visited Nov. 2, 2014) (discussing results of poll of 1,017 adults taken Oct. 12-15). 
million Americans have been jobless for 27 weeks or more. ${ }^{214}$ An additional 7.1 million Americans are working part-time because they have been unable to secure full-time employment. ${ }^{215}$ And those unemployment statistics don't count the nearly 3 million Americans who want jobs but have given up because they don't think any are available. ${ }^{216}$ Most of the job growth since the recession has been concentrated in lowwage jobs. ${ }^{217}$ As a result, workers cannot lightly leave their jobs, especially relatively high-paying ones at Hobby Lobby, under the assumption that they will easily find substitute employment.

\section{ii. The Decision Has Especially Worrisome Effects on Women's Labor - and Women's Bodies}

The problem is particularly acute for women, who are the focus of Hobby Lobby even if the majority elides their concerns. ${ }^{218}$ Women are still disproportionately the

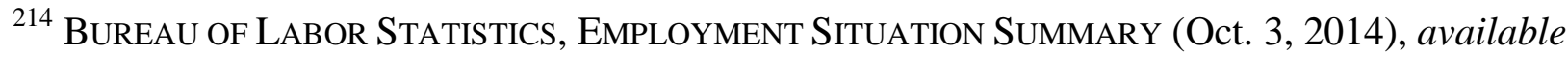
at http://www.bls.gov/news.release/empsit.nr0.htm.

${ }^{215} \mathrm{Id}$.

${ }^{216}$ This figure includes both "marginally attached" workers who have looked for jobs in the past twelve months, but not the past four weeks, and the "discouraged workers" who are "not currently looking for work because they believe no jobs are available for them." Id.; see also Alan B. Krueger, et al., Are the Long-Term Unemployed on the Margins of the Labor Market? (Brookings Papers on Economic Activity 229, Spring 2014), available at http://www.brookings.edu/ /media/projects/bpea/spring\%202014/2014a_krueger.pdf (finding that the longer workers are unemployed, the less attached they become to the labor force).

${ }^{217}$ See NATiOnal Employment Law PROJECT, An Unbalanced Recovery (Aug. 2014), available at http://www.nelp.org/page/content/Unbalanced-Recovery/.

${ }^{218}$ See, e.g., Hobby Lobby, 134 S. Ct. at 2760 ("The effect of the HHS-created accommodation on the women employed by Hobby Lobby and the other companies involved in these cases would be precisely zero.”); see generally Elizabeth Sepper, Gendering Corporate Conscience, 39 HARV. J.L. \& GENDER (Forthcoming 2014); Gedicks \& Koppelman, supra note 173. 
primary caregivers in families, ${ }^{219}$ even though the majority of mothers are in the workforce. ${ }^{220}$ And those women workers receive less pay, on average, than men: 81 cents on the dollar. ${ }^{221}$ In the retail sector, the disparity is even worse: the median weekly earnings for a retail salesman is $\$ 719$; for a retail saleswoman, only $\$ 485 .^{222}$

Yet it is those same women employees who will be left to rely on government largesse for contraceptive coverage if their employer objects, or risk becoming pregnant. As Justice Ginsburg discussed in her dissent, Hobby Lobby was particularly concerned about funding insurance coverage of intrauterine devices, or IUDs. ${ }^{223}$ Inserting an IUD can cost up to $\$ 1,000$ upfront. ${ }^{224}$ To a worker earning the federal minimum wage, that equates to 138 hours of work - or nearly one month's worth - not considering taxes. ${ }^{225}$ Given the effectiveness of the IUD compared to other forms of birth control, ${ }^{226}$ though, that $\$ 1,000$ is not the only amount that matters. According to a USDA study, the

${ }^{219}$ See AMERICAN Psychological Association, Who Are Family Caregivers?, http://www.apa.org/pi/about/publications/caregivers/faq/statistics.aspx (last visited Nov. 6, 2014).

${ }^{220}$ Bureau of Labor Statistics, EMPloyment Status of Parents: 2011 (Apr. 27, 2012), available at http://www.bls.gov/opub/ted/2012/ted_20120427.htm.

${ }^{221}$ BUREAU OF LABOR STATISTICS, WOMEN's EARNiNGS, 1979-2012 (Nov. 4, 2013), available at http://www.bls.gov/opub/ted/2013/ted_20131104.htm.

${ }^{222}$ Bureau of LABOr Statistics, Labor ForCe Statistics from the CURRENT Population SURVEY (Feb. 26, 2014), available at http://www.bls.gov/cps/cpsaat39.htm.

${ }^{223}$ Hobby Lobby, 134 S. Ct. 2751, 2800, n.22 (2014) (Ginsburg, J. dissenting).

${ }^{224}$ The IUD at a Glance, PLANNED PARENTHOOD, http://www.plannedparenthood.org/healthinfo/birth-control/iud.

${ }^{225}$ The Federal minimum wage is $\$ 7.25$ per hour. U.S. DEPT. OF LABOR, MinimUM WAGE, http://www.dol.gov/dol/topic/wages/minimumwage.htm. Assuming a 40 hour workweek and no deductions or taxes, that equals $\$ 290$ per week.

${ }^{226}$ Brooke Winner, et al., Effectiveness of Long-Acting Reversible Contraception, 366 N. ENGL. J. MED. 2012 (2012) (finding that the failure rate among participants using birth control pills, patches, or rings was 4.55 per 100 participant-years, as compared with 0.27 among participants using long-acting reversible contraception, including IUDs). 
average cost of raising a child until age 18 is $\$ 241,080 .^{227}$ To a Supreme Court justice who earns $\$ 244,400$ per year, ${ }^{228}$ that may not seem like a daunting sum. But to a single mother who earns \$28,000 a year as a Hobby Lobby cashier, for example, whether contraception works or not can mean the difference between poverty and providing for the children she has, or between taking on extra shifts to advance on the corporate ladder or saying no to avoid the cost of childcare. Even for a dual-earning couple making $\$ 80,000$ a year, the prospect of paying $\$ 20,000$ a year for college for one or two kids might be doable, but is simply not feasible for many or any more. ${ }^{229}$ There is a reason why more than $99 \%$ of women aged 15-44 who have ever had sex have used at least one contraceptive method. ${ }^{230}$ And the birth control pill, in addition to being less effective than an IUD and more prone to human error, can produce bad side effects or be medically inadvisable for some women. Some women, in other words, need access to the IUD as the most reliable and longest-lasting medically safe contraceptive. ${ }^{231}$ The Affordable Care Act thus set access to the contraceptive method of a woman's own choosing as part

${ }^{227}$ U.S. DePT. OF Agriculture, EXPENDITURES ON CHILDREN by FAMiLIES (Aug. 2014), available at http://www.cnpp.usda.gov/ExpendituresonChildrenbyFamilies.

${ }^{228}$ UNITED STATES COURTS, JUDICIAL SALARIES SINCE 1968, available at http://www.uscourts.gov/JudgesAndJudgeships/JudicialCompensation/judicial-salaries-since1968.aspx.

${ }^{229}$ For the 2011-12 school year, the average total tuition, fees, room and board rates charged for full-time undergraduate students in degree-granting institutions was $\$ 19,339$. Given the historical trajectory (the comparable figure for 1981-82 was $\$ 3,489$, in inflation-adjusted terms), it is reasonable to assume that parents of children born today can expect to pay much more than that 18 years hence. See NATIONAL CENTER FOR EduCATION STATISTICS, Tuition Costs of Colleges and Universities, available at http://nces.ed.gov/fastfacts/display.asp?id=76.

${ }^{230}$ GUTTMACher InSTituTe, Fact Sheet: Contraceptive Use in the United States (June 2014), available at http://www.guttmacher.org/pubs/fb_contr_use.html.

${ }^{231}$ The IUD At a Glance, http://www.plannedparenthood.org/health-info/birth-control/iud. 
of its minimum essential guarantee. The decision in Hobby Lobby amounts to a veto by the employer of that guarantee.

\section{iii. Self-Described “Corporate Religion” Goes Beyond Hobby Lobby - and Thus, Beyond Hobby Lobby}

Although Hobby Lobby is one of the largest self-described religious employers, it is far from alone at the corporate pew. At least fifty other for-profit companies also challenged the contraceptive mandate in court. ${ }^{232}$ There are a number of other large companies who identify themselves with religious beliefs, including Chick-fil-A, which closes on Sundays, consistent with the purpose described on its website "[t]o glorify God by being a faithful steward of all that is entrusted to us." ${ }^{233}$ The company has over 1,850 locations and annual sales of over $\$ 5$ billion. ${ }^{234}$ Mary Kay, with $\$ 3.5$ billion in annual revenues and three million employees, ${ }^{235}$ has been repeatedly criticized by (former)

${ }^{232}$ See National Women's Law Center, Status of the Lawsuits Challenging the Affordable Care Act's Birth Control Coverage Benefit (Nov. 3, 2014), available at http://www.nwlc.org/sites/default/files/pdfs/contraceptive_coverage_litigation_status_11-0314_finall.pdf.

${ }^{233}$ Corporate Information, CHICK-FIL-A, http://www.chick-fil-a.com/FAQ\#?category=2 ("What is the Corporate Purpose of Chick-fil-A, Inc.?) (last visited Nov. 10, 2014). That purpose is not actually reflected in its corporate charter, which suggests that any religious actions may be ultra vires. Chick-fil-A, Inc. was first incorporated in 1964, and has amended its charter multiple times since then, most recently in 2008, but has never reflected a religious purpose. Under the current version of the charter, "[t]he purpose of the Corporation is to engage in any form or type of business for any lawful purpose or purposes not specifically prohibited to corporations for profit under the laws of the State of Georgia and to have all the rights, powers, privileges and immunities which are now or hereafter may be allowed to corporations under the laws of the State of Georgia.” Second Amended and Restated Articles of Incorporation of Chick-fil-A, Inc., May 15, 2007.

${ }^{234}$ Company Fact Sheet, CHICK-FIL-A, http://www.chick-fil-a.com/Company/Highlights-FactSheets (last visited Nov. 10, 2014).

${ }^{235}$ Company Quick Facts, MARY KAY, http://www.marykay.com/en-US/About-MaryKay/CompanyFounder/Pages/Company-Quick-Facts.aspx (last visited Nov. 10, 2014). 
employees for fostering a proselytizing, cult-like atmosphere ${ }^{236}$ imbued by founder Mary Kay’s oft-repeated motto of “God first, family second, career third.”237 Nor are all religiously-affiliated companies private: Tyson Foods, a \$34.4 billion public corporation, ${ }^{238}$ describes its culture as "faith-friendly.", 39 Accordingly, the company employs 120 office chaplains to provide "compassionate pastoral care” to its 115,000 employees. $^{240}$

\section{iv. Hobby Lobby's Authorization of Incursions on Workers' Freedom Comes on Top of Other Employer Intrusions}

Not only does Hobby Lobby leave workers vulnerable to employers who deny them the full range of rights Congress has said must come with a job, the decision comes at a time when employers are, for economic reasons, impinging on worker's freedom in other ways. At least partly because of a desire to control the costs of providing health care, many employers require employees to undergo testing for the use of tobacco

${ }^{236}$ See, e.g., Religious Abuse in Mary Kay, PINK TRUTH (2013), available at http://www.pinktruth.com/2013/08/religious-abuse-in-mary-kay/; Faith and Facials: The Religion of Mary Kay, ORLANDO SENTINEL, Jan. 4, 1997, available at http://articles.orlandosentinel.com/1997-01-04/lifestyle/9701021026_1_mary-kay-ash-god-first ("Such open discussion of religion, combined with consultants' strong allegiance to [founder Mary Kay] Ash, has led some critics to call the company a cult, according to Michigan independent senior sales director Jo Carlson .... 'We're mistreated when they call us a cult,' says Carlson. 'Mary Kay is a Christian and she's proud of it.'”).

${ }^{237}$ Our Values, MARY KAY, http://www.marykay.com/en-US/About-Mary-

Kay/EmploymentMaryKay/Pages/OurValues.aspx (last visited Nov. 10, 2014).

${ }^{238}$ Fiscal 2013 Facts, TYSON FOODS, http://ir.tyson.com/investor-relations/investoroverview/tyson-factbook/default.aspx.

${ }^{239}$ Faith in the Workplace, TysON FoODs, http://www.tysonfoods.com/ways-we-care/faith-inthe-workplace.aspx (last visited Nov. 10, 2014).

${ }^{240}$ Fiscal 2013 Fact Book 1, Tyson FoODS, available at http://ir.tyson.com/files/doc_downloads/Tyson\%202013\%20Fact\%20Book.pdf; Chaplain Services, http://www.tysonfoodscareers.com/Working-At-Tyson/Tyson-Benefits/ChaplainServices.aspx. 
products $^{241}$ and even to suffer consequences for obesity. ${ }^{242}$ Drug testing is now a common practice among employers. ${ }^{243}$ Eavesdropping on workers' phone calls and use of computer technology is growing - and according to a 2010 U.S. Supreme Court decision, perfectly legal, even when the government is the employer. ${ }^{244}$ Professor Henderson has called this the "New Nannyism" and documented the rapid growth in such practices. ${ }^{245}$ Hobby Lobby now presents employers an opportunity to couch economically motivated tactics for controlling employer behavior in religious terms, thus putting the muscle of RFRA behind their profit objectives.

\section{v. Protecting the Rights of the Few (Employers) over the Many (Workers)}

As the parties involved in Hobby Lobby illustrate - i.e., the five members of the Green family who control the company compared to the 23,000 individuals who work there - there are many more American employees than American employers. Hobby Lobby thus elevates the rights of the few over those of the many. Moreover, the decision not only comes at a time when workers are poorly positioned to abandon jobs they have, but also when there is a long-term growth in inequality. Since 1979, the after-tax real

${ }^{241}$ See Henderson, supra note 37.

${ }^{242}$ See Luann Heinen \& Helen Darling, Addressing Obesity in the Workplace: The Role of Employers, 87 MiLBANK Q. 101 (2009), available at http://www.ncbi.nlm.nih.gov/pmc/articles/PMC2879173/.

${ }^{243}$ Workplace Drug Testing, ACLU (Mar. 12, 2002), https://www.aclu.org/racialjustice_womens-rights/workplace-drug-testing (noting that employer drug testing increased 277\% from 1987 to 2002).

${ }^{244}$ City of Ontario v. Quon, 560 U.S. 746 (2010) (holding that police department's review of officer's text messages was reasonable, and did not violate the Fourth Amendment).

${ }^{245}$ See Henderson, supra note 37. 
incomes of the top $1 \%$ have tripled. ${ }^{246}$ During the same period, after-tax income for households in the middle three-fifths of the income distribution grew by only $40 \% .{ }^{247}$

The median household income, now $\$ 51,939$, has decreased by $6.6 \%$ since $2000 .{ }^{248}$ And since the Great Recession, most of the gains of the recovery have accrued to the top: according to economist Emmanuel Saez, top 1\% incomes increased by over 30\% between 2009 and 2012, compared to $0.4 \%$ growth for the bottom 99\%. ${ }^{249}$ American income inequality is the greatest it has been since the early 1980s. ${ }^{250}$ Among all OECD countries, only Chile has greater income inequality than the U.S. ${ }^{251}$

If economic inequality continues to increase and to make it difficult for even those with a job to enjoy the attributes of the American Dream - decent housing, good health care, and the ability to send one's children to college - it is important that Congress have the power to keep the social safety net secure and foster a healthy middle class. But Hobby Lobby is not an isolated judicial decision. It comes on top of other important

\footnotetext{
${ }^{246}$ Gary Burtless, Income Growth and Income Inequality: The Facts May Surprise You, BROOKINGS INSTITUTION (Jan. 6, 2014), http://www.brookings.edu/research/opinions/2014/01/06-income-gains-and-inequality-burtless. ${ }^{247} I d$.

${ }^{248}$ U.S. Census Bureau, Median Household Income in the Past 12 Months by State and PUERTO RICO: 2000, 2011, AND 2012, http://www.census.gov/prod/2013pubs/acsbr12-02.pdf (last visited Nov. 6, 2014).

${ }^{249}$ Emmanuel Saez, Striking it Richer: The Evolution of Top Incomes in the United States (Sept. 3, 2013), http://eml.berkeley.edu/ saez/saez-UStopincomes-2012.pdf.

${ }^{250}$ Drew DeSilver, 5 Facts About Economic Inequality, Pew ReSEARCH Center (Jan. 7, 2014), http://www.pewresearch.org/fact-tank/2014/01/07/5-facts-about-economic-inequality/.

${ }^{251} I d$. (including all taxes and transfers). Wealth inequality is even greater; the bottom $50 \%$ of families own zero wealth. Emmanuel Saez, Evidence on Income and Wealth Inequality 3 (Nov. 2014), on file with author. The top $0.1 \%$ of households $(160,000$ families with total net assets of more than \$20 million) own 22\% of total household wealth. Emmanuel Saez \& Gabriel Zucman, Exploding Wealth Inequality in the United States, Vox (Oct. 28, 2014), available at http://www.voxeu.org/article/exploding-wealth-inequality-united-states.
} 
recent decisions, notably Citizens United ${ }^{252}$ and the part of the National Federation of Independent Business v. Sebelius ${ }^{253}$ that invalidated the ACA's Medicaid expansion, both of which have a constraining effect on the ability of our elected officials to protect workers and the economically vulnerable more generally. Taken together, these decisions create a distinct pattern: Hobby Lobby provides a wide-ranging basis for employers to object to participating in secular programs designed to provide a basic guarantee of living standards to workers. It also gives rise to arguments against adopting new protections because opponents can argue they must be designed to accommodate expensive work-arounds by employers with religious objections. Citizens United provides corporations with the power to use massive amounts of money to influence the electoral process to dampen society's ability to regulate externalities and expand the social safety net. ${ }^{254}$ And Sebelius limits the ability of Congress to increase the scope of

${ }^{252}$ Citizens United v. Fed. Election Comm'n., 558 U.S. 310 (2010).

${ }^{253}$ Nat'l Fed'n of Indep. Bus. v. Sebelius, 132 S. Ct. 2566 (2012).

${ }^{254}$ If campaign contributions and expenditures are made for business purposes, they are most likely to be designed to influence the political process in a manner that relaxes the regulatory strictures under which corporations operate - strictures that do things such as protect the environment and consumers, and promote worker safety. Likewise, these contributions are also likely to be made to candidates who oppose expansion of the social safety net, if the sources of support for such an expansion would involve any increased obligations on the business sector. For example, Chevron recently spent over $\$ 3$ million to try to elect a municipal government in Richmond, Virginia, that would not advocate for improved safety measures at a refinery which has had at least three major fires erupt in the last quarter-century. See "Progressives Capture City Hall and Council, Fending Off Chevron Money,” RichmOND ConfidenTIAL (Nov. 5, 2014), available at http://richmondconfidential.org/2014/11/05/progressives-capture-city-hall-andcouncil-fending-off-chevron-money/; Heather Smith, In Richmond, Calif., It's Chevron's \$3 Million vs. A Green Slate, http://grist.org/politics/in-richmond-calif-its-chevrons-3-million-vs-agreen-slate. See generally Leo E. Strine, Jr. \& Nicholas Walter, Conservative Collision Course?: The Tension Between Conservative Corporate Law Theory and Citizens United, 100 CORNELL L. REV. (forthcoming Jan. 2015) (compiling evidence of large corporate spending on political and lobbying efforts to influence regulatory policy). 
existing federal programs that involve federal-state partnerships, even when Congress has expressly reserved the right to amend the program. ${ }^{255}$ What all three decisions have in common is that they constrain the ability of Congress to regulate businesses effectively and to provide a floor for working Americans.

\section{The Implications of Hobby Lobby for Corporate Law}

The Supreme Court's decision in McCutcheon v. Federal Election Commission, 134 S. Ct. 1434 (2014), adds to these risks. McCutcheon invalidated the limit on total contributions to candidates imposed by the Bipartisan Campaign Reform Act of 2002, popularly known as the McCainFeingold Act. In finding that the limit was unconstitutional, the majority waxed at length on its own view of political realities, and gave little weight to the bipartisan findings of Congress, a group of people who know how politics works. See id. at 1453-1457. By allowing virtually unlimited sums to flow to candidates, including from corporate donors, McCutcheon, like Citizens United, expands the influence of the "haves" over the electoral process. Cf. Shelby County v. Holder, 133 S. Ct. 2612 (2013) (holding key parts of the Voting Rights Act unconstitutional).

The effects of these decisions are already being felt: the 2014 midterm election was the most expensive one in history, with a total projected cost of \$3.67 billion. Russ Choma, Money Won on Tuesday, But Rules of the Game Changed, Center fOr Responsive Politics (Nov. 5, 2014), available at https://www.opensecrets.org/news/2014/11/money-won-on-tuesday-but-rules-ofthe-game-changed/. And much of that money was apparently well-spent: the candidate who spent the most won in $94.2 \%$ of House races, and $81.8 \%$ of Senate races. Id. In 36 races, outside groups outspent the candidate. Id. Some observers attribute these changes directly to McCutcheon: "When the ruling in McCutcheon v. FEC was handed down, many campaign finance observers predicted that it would empower a new class of elite donors and lead to the creation of massive joint fundraising committees - teams of candidates, party committees and other groups that could pursue big donors together and split the proceeds of a single giant check. Both of those things occurred in 2014.” Id.

${ }^{255}$ In what is an odd piece of reasoning, the Sebelius majority found that Medicaid - a federal program - was now such a fundamental a part of society that states needed to continue to participate. Sebelius, $132 \mathrm{~S}$. Ct. at 2603. But it then held that their right to act as separate sovereigns prevented Congress from conditioning states' participation in Medicaid on their willingness to abide by the expanded program Congress adopted, even with a phase-in period mainly reliant on federal funds. Id. States therefore get to embrace social progress enacted by Congress by claiming it to be fundamental to their governance, but can assert that any expansion infringes upon their rights as independent sovereigns. By this means, the Supreme Court has threatened Congress' ability to expand the social safety net. Of course, as in Hobby Lobby, the Court has a simple answer, which is that federal taxpayers can fund the expansion alone, just as non-objecting taxpayers can fund health care for the workers of religious employers. 
There is another important implication of Hobby Lobby, which also works in concert with Citizens United. As I have observed in other work, ${ }^{256}$ Citizens United creates problems for corporate law because it weakens the argument that the concerns of other corporate constituencies should be addressed by bodies of law external to corporate law. Hobby Lobby compounds those problems.

The majority's understanding of corporate law is in seeming tension with itself. Much of its reasoning is based on a selective reading of corporate law sources strung together to stand for the proposition that as a general matter of American corporate law, for-profit corporations may treat as ends other interests than simply stockholder welfare. Thus, the majority indicates that for-profit corporations may consider interests, including those of their workers, consumers, or the communities in which the corporations operate. $^{257}$

Oddly, the majority even cites to the adoption of a specific new form of business entity, the Benefit Corporation, by many states, including my own. ${ }^{258}$ A Benefit Corporation is one that is expressly chartered with the obligation not just to pursue stockholder profit as an end but also to pursue other ends benefiting the public interest, such as the environment. ${ }^{259}$ The irony in the majority's reasoning is that Benefit Corporations were created by statute precisely to enable corporations to consider other constituencies without running afoul of the law.

256 See generally Strine \& Walter, supra note 254.

${ }^{257}$ Hobby Lobby, 134 S. Ct. at 2770-71.

${ }^{258} \mathrm{Id}$. at 2771.

${ }^{259}$ See 8 Del. C. § 362. 
Delaware’s legal framework is instructive: unlike many other American states, Delaware does not have a so-called constituency statute, and the Benefit Corporation statute was especially noteworthy, because Delaware case law is clear that the board of directors of a for-profit corporation chartered under the Delaware General Corporation Law (“DGCL”) must, within the limits of its legal discretion, treat stockholder welfare as the only end, considering other interests only to the extent that doing so is rationally related to stockholder welfare. ${ }^{260}$ As Chancellor William T. Allen once observed,

I take it as non-controversial that, under established and conventional conceptions, directors owe duties of loyalty to the corporation and to the shareholders; that this conjunctive expression is not usually problematic because the interests of the shareholders as a class are seen as congruent with those of the corporation in the long run; that directors, in managing the business and affairs of the corporation, may find it prudent (and are authorized) to make decisions that are expected to promote corporate (and shareholder) long run interests, even if short run share value can be expected to be negatively affected, and thus directors in pursuit of long run corporate (and shareholder) value may be sensitive to the claims of other "corporate constituencies." Thus, broadly, directors may be said to owe a duty to shareholders as a class to manage the corporation within the law, with due care and in a way intended to maximize the long run interests of shareholders. ${ }^{261}$

For reasons explained by corporate scholars and thinkers such as Milton Friedman, stockholders are not well-positioned to monitor managers who use the corporation for ${ }^{260}$ See Revlon, Inc. v. MacAndrews \& Forbes Holdings, Inc., 506 A.2d 173, 182 (Del. 1986) (holding that a board can only consider the interests of other constituencies only if "rationally related benefits accru[e] to the stockholders").

${ }^{261}$ TW Services, Inc. v. SWT Acquisition Corp., 14 DeL. J. CoRP. L. 1169, 1183 (Del. Ch. 1989); see also eBay Domestic Holdings, Inc. v. Newmark, 16 A.3d 1, 34 (Del. Ch. 2010) ("Directors of a for-profit Delaware corporation cannot deploy a rights plan to defend a business strategy that openly eschews stockholder wealth maximization - at least not consistently with the directors' fiduciary duties under Delaware law."); Leo E. Strine, Jr., Making It Easier for Directors to "Do the Right Thing”?, 4(2) HARV. Bus. L. REV. 235, 241 (2014) (collecting case citations supporting the principle that "corporate law makes corporate managers accountable to only one constituency - stockholders"). 
purposes unrelated to profit, and it is thus illegitimate for managers to do so. ${ }^{262}$ As Justice Scalia, a member of the Hobby Lobby majority, once put it: “The Campbell Soup Company does not exist to promote a message ....”263

As scholars have also pointed out, Hobby Lobby also ignores basic aspects of corporate law, particularly the nature of the corporation as legally distinct from its stockholders. ${ }^{264}$ When it focused on Hobby Lobby’s purported religious beliefs, the Court gave heavy weight to the fact that the company's equity was wholly owned by the Green family, and that the family had shared religious beliefs. ${ }^{265}$ It ignored any potential tension between the interests of the corporation - which the Court noted was a separate “person” under RFRA with its own distinct legal identity - and the interests of the individual stockholders. ${ }^{266}$ Indeed, the majority frequently conflated the interests of the Greens with the interests of Hobby Lobby. ${ }^{267}$

${ }^{262}$ See Milton Friedman, The Social Responsibility of Business Is to Increase Its Profits, N.Y. Times MAG. (Sept. 13, 1970); see also Michael C. Jensen \& William H. Meckling, Theory of the Firm: Managerial Behavior, Agency Costs and Ownership Structure, 3 J. FIN. ECON. 305 (1976). ${ }^{263}$ Washington State Grange v. Washington State Republican Party, 552 U.S. 442, 467 (2008) (Scalia and Kennedy, JJ., dissenting).

${ }^{264}$ See, e.g., Brief for Corporate and Criminal Law Professors as Amici Curiae Supporting Petitioners, Hobby Lobby, No. 13-354 2 (U.S. Jan. 28, 2014).

${ }^{265}$ Having been on the Delaware Court of Chancery for over fifteen years, I also observe that the fact that members of the same family hold all of a corporation's shares does not invariably mean that they share the same views about the company's business plan, much less the same religious beliefs.

${ }^{266}$ See, e.g., Morton J. Horwitz, Santa Clara Revisited: The Development of Corporate Law Theory, 88 W. VA. L. REV. 173, 181 (1985) (discussing the critical distinction between the corporation and its managers or owners); David Millon, Theories of the Corporation, 1990 DUKE L.J. 201, 205-212 (1990); see also Steven Davidoff Solomon, In Hobby Lobby Ruling, a Missing Definition Stirs Debate, N.Y. TIMES, Sept. 2, 2014, available at http://dealbook.nytimes.com/2014/09/02/in-hobby-lobby-ruling-a-missing-definition-stirs-debate ("Many corporate law experts have been skeptical of the logic behind the Hobby Lobby decision. The reason is that one of the chief benefits of a for-profit company is that it has limited liability. 
But the Hobby Lobby employees at risk of losing employer coverage for contraceptives are employed by the company - a distinct legal entity - not the Green family itself. That separation provides huge benefits to the corporation and to those who own its equity, including perpetual life for the corporation and limited liability for stockholders. ${ }^{268}$ At least in Delaware, if a corporation wishes to have a religious purpose, the traditional method is to set forth that purpose in the corporation's certificate of incorporation. ${ }^{269}$ Equity ownership alone, even ownership of all the equity, neither subjects a stockholder to liability for corporate conduct, nor entitles that owner to control corporate affairs. Rather, what majority control secures is the power for the equity owner to manage the corporation in accordance with the DGCL and the principles of Delaware common law. Those principles do not allow a fiduciary to place any self-interest, including personal, social, political, or religious beliefs, above the duty to have the

Shareholders cannot be held responsible for the debts of the company because it exists separately. Because of this, imputing the intent of the shareholders has always been on thin ice from a corporate law perspective because having a separate existence is the whole reason for creating a corporation in the first place.”).

${ }^{267}$ See, e.g., Hobby Lobby, 134 S. Ct. at 2775 ("By requiring the . . . Greens and their company[y] to arrange for such coverage, the HHS mandate demands that they engage in conduct that seriously violates their religious beliefs. If the ... Greens and their company[y] do not yield to this demand, the economic consequences will be severe.").

${ }^{268}$ Admittedly, perpetual life may depend on the fate of humanity, which may be determined not only by human behavior, but by chance (a meteor strike of the wrong kind could be very bad), or, of course, a creator such as God in the Jewish, Muslim or Christian sense.

2698 Del. C. § 102(a) (“The certificate of incorporation shall set forth: (3) The nature of the business or purposes to be conducted or promoted. It shall be sufficient to state, either alone or with other businesses or purposes, that the purpose of the corporation is to engage in any lawful act or activity for which corporations may be organized under the General Corporation Law of Delaware, and by such statement all lawful acts and activities shall be within the purposes of the corporation, except for express limitations, if any.”). Of course, that does not mean the corporation can have religious beliefs of its own: "a business organization does not have religious beliefs. Rather, as it has been famously put, 'a corporation has no soul.”' Thomas E. Rutledge, A Corporation Has No Soul: The Business Entity Law Response to Challenges to the PPACA Contraceptive Mandate, 5 WM. \& MARY Bus. L. REV., 1, 5 (2014). 
corporation seek stockholder welfare as its only end, within the limits of its legal discretion. ${ }^{270}$

The majority elided the distinction between the company and its stockholders, even though it was not unaware of the concern: forty-four corporate law professors signed onto an amicus brief, noting:

The essence of a corporation is its "separateness" from its shareholders. It is a distinct legal entity, with its own rights and obligations, different from the rights and obligations of its shareholders .... When they voluntarily choose to incorporate a business, shareholders cannot then decide to ignore, either directly or indirectly, the distinct legal existence of the corporation when it serves their personal interests. ${ }^{271}$

Moreover, the majority ignored another critical question: who can decide what the corporation's religion is? In justifying why for-profit corporations like Hobby Lobby can have religious beliefs worthy of protection under the RFRA, the majority cites to state laws allowing corporations to treat interests other than stockholder welfare as ends in

${ }^{270}$ See, e.g., Revlon, Inc. v. MacAndrews \& Forbes Holdings, Inc., 506 A.2d 173, 182 (Del. 1986); see also N. Am. Catholic Educ. Programming Found., Inc. v. Gheewalla, 930 A.2d 92, 101 (Del. 2007) ("The directors of Delaware corporations have 'the legal responsibility to manage the business of a corporation for the benefit of its shareholder[] owners."' (quoting Malone v. Brincat, 722 A.2d 5, 9 (Del. 1998))); In re Trados Inc. S'holder Litig., 73 A.3d 17, 40-41 (Del. Ch. 2013) ("[T]he standard of conduct for directors requires that they strive in good faith and on an informed basis to maximize the value of the corporation for the benefit of its residual claimants, the ultimate beneficiaries of the firm's value ....”); eBay Domestic Holdings, Inc. v. Newmark, 16 A.3d 1, 33 (Del. Ch. 2010) ("Promoting, protecting, or pursuing non-stockholder considerations must lead at some point to value for stockholders.”); TW Servs., Inc. v. SWT Acquisition Corp., 1989 WL 20290, at *7 (Del. Ch. Mar. 2, 1989); Katz v. Oak Indus. Inc., 508 A.2d 873, 879 (Del. Ch. 1986) ("It is the obligation of directors to attempt, within the law, to maximize the long-run interests of the corporation's stockholders ....”); William T. Allen, Ambiguity in Corporation Law, 22 DeL. J. CoRP. L. 894, 896-97 (1997) ("[T]he proper orientation of corporation law is the protection of long-term value of capital committed indefinitely to the firm.”).

${ }^{271}$ Brief for Corporate and Criminal Law Professors as Amici Curiae Supporting Petitioners, Burwell v. Hobby Lobby Stores, Inc., 134 S. Ct. 2751 (2014) (Nos. 13-354, 13-356), 2014 WL 333889. 
themselves. ${ }^{272}$ But in examining who determines the corporation's religious beliefs, the majority focuses only on who is in effective control of corporate power, the managers (directors and officers) who derive their power solely from one corporate constituency, the stockholders. The Court's underlying ruling, thus, is that whoever manages a corporation under its governing documents and state law may, when in power, decide what the corporation's policies are, including any religious values. For that reason, even corporate scholars sympathetic to a multi-constituency focus in corporate law have observed the tension in the reasoning. ${ }^{273}$ Put simply, these other constituencies appear to have been useful purely as an instrument to the majority's justification for allowing corporate managers to use the corporate entity as a vehicle for the expression of their own religious beliefs, solely by virtue of having managerial control.

Indeed, the practical result of the Supreme Court's holding is that HHS must now define which organizations are eligible to opt out of the contraceptive mandate. A number of corporate law professors have responded to HHS' request for comments from the public, arguing that the ruling should be narrowly cabined. They grounded their argument in substantive corporate law and the reality that the distinction between equity holders and the entity itself is central to corporate law, and the related fact that equity investors do not typically invest in for-profit corporations to express religious beliefs. One group of corporate law professors, all from the University of California, Berkeley

${ }^{272}$ Hobby Lobby, 134 S. Ct. at 2771-72.

${ }^{273}$ See Lyman Johnson, Corporate Law After Hobby Lobby, 70 Bus. LAw. (forthcoming Nov. 2014) at 24-25, available at http://papers.ssrn.com/sol3/papers.cfm?abstract_id=2507406; see also Churchill, supra note 148; Larry E. Ribstein, The First Amendment and Corporate Governance, 27 GA. ST. U. L. REV. 1019 (2011). 
School of Law, take a simple approach and contend that a corporation should be able to claim religious beliefs worthy of an accommodation under RFRA only if the corporation is willing to certify that the extremely onerous conditions for veil-piercing exist as an ongoing matter and that the corporation is nothing more than the alter ego of the equity owners and the equity owners share a religious belief. ${ }^{274}$ Another broader group of distinguished corporate law professors would limit the exception developed in Hobby Lobby to closely-held corporations and then only under certain conditions: "entities (1) with a limited number of equity holders/owners, (2) that demonstrate religious commitment, and (3) submit evidence of unanimous consent of equity holders to seek an accommodation on an annual basis." 275 In both of these efforts, the professors point out that Hobby Lobby's reasoning does not fit well with corporate law itself, and that “close corporation” is not a precise term in corporate law. Both letters also advocate interpreting Hobby Lobby narrowly and ignoring the language in the opinion that whoever is seated as the board of directors gets to imbue the corporation with their

${ }^{274}$ Robert P. Bartlett, et al., Comment on the Definition of 'Eligible Organization' for Purposes of Coverage of Certain Preventive Services under the Affordable Care Act, Oct. 8, 2014, available at http://papers.ssrn.com/sol3/papers.cfm?abstract_id=2507305.

${ }^{275}$ Katherine Franke, et al, Comment on the Definition of "Eligible Organization" for Purposes of Coverage of Certain Preventative Services Under the Affordable Care Act, Oct. 21, 2014, available at https://web.law.columbia.edu/sites/default/files/microsites/gendersexuality/prpcp_comments_on_proposed_regs_corp_law_profs_for_submission.pdf. Notably, these professors cite to Delaware's close corporation model for a definition of a close corporation when a state does not have its own criteria. In this regard, however, it is notable that the Delaware close corporation statute is a rarely-used subsection of the overall DGCL, and most closely held corporations are governed by the general provisions of the DGCL and not the special close corporation subchapter. See 2 David A. Drexler et al., Delaware Corporation Law and Practice § 43.01, at 43-1 (2013). There are many reasons for that reality, including that most for-profit corporations want the flexibility to raise additional capital and go public if the business is successful. 
religious beliefs, and that if those beliefs are not acceptable to some stockholders, those stockholders must unseat the board or otherwise remove that subject matter from their power.

Perhaps most interestingly, many of the points I have made here about the majority’s approach to corporate law are reflected in a letter from several law professors for whom I have enormous respect that takes the opposite approach, and attempts to convince HHS to make the Hobby Lobby exemption more broadly available. ${ }^{276}$ Although these scholars' perception of the social utility of Hobby Lobby is quite different than mine, they also read the decision's logic as impossible to cabin to closely-held corporations whose equity owners are unanimous in their religious views. To the contrary, these scholars embrace the notion that the corporation is a distinct entity from its stockholders, and that the board of directors is the organ charged with setting corporate policies within the limits of their legal and equitable discretion. ${ }^{277}$ They argue that corporate directors have wide flexibility under Delaware corporate law to chart a course in the best interests of stockholders, and under other state laws, do not even have to put stockholders above other constituencies. They note that although the Supreme Court cited to close corporation statutes and the new benefit corporation statutes, most corporations are not incorporated under such statutes - including Hobby Lobby itself. ${ }^{278}$ They also point out that terms like "family owned" have no corporate law meaning at all,

${ }^{276}$ Lyman Johnson, et al., Comments on the HHS’ Flawed Post-Hobby Lobby Rules, at 2 (Oct. 20, 2014), available at http://papers.ssrn.com/sol3/papers.cfm?abstract_id=2512860.

${ }^{277} I d$. at 4.

${ }^{278} I d$. at 7. 
and that most corporations whose stock is owned by members of a family are incorporated under the same statutes that large, public corporations use to govern their internal affairs. ${ }^{279}$ Although these scholars have a normative take on Hobby Lobby that is different than mine, I largely share their view that the Court's reasoning, if taken seriously, cannot be cabined to close corporations whose equity is owned by a small group of like-minded stockholders. ${ }^{280}$

The vigorous debate among these scholars about the implications of the Court's reasoning in Hobby Lobby illustrates another important consequence of the decision: Hobby Lobby puts great pressure on corporate law itself. That is so for a few reasons. First, as some scholars have pointed out, if both Citizens United and Hobby Lobby are correct and the corporation has a multi-constituency focus, why are its religious values determined by reference to the equity owners and who they decide to elect? ${ }^{281}$ Why not

${ }^{279} I d$. at 6.

${ }^{280}$ But their suggestion that boards of directors of for-profit corporations in a state like Delaware can adopt political or religious views and advance them at the expense of stockholders, absent a specific charter provision elevating those views above stockholder welfare, is difficult to square with the precedent. See, e.g., eBay Domestic Holdings, Inc. v. Newmark, 16 A.3d 1, 34 (Del. Ch. 2010) ("The corporate form in which craigslist operates, however, is not an appropriate vehicle for purely philanthropic ends, at least not when there are other stockholders interested in realizing a return on their investment. ... Having chosen a for-profit corporate form, the craigslist directors are bound by the fiduciary duties and standards that accompany that form. Those standards include acting to promote the value of the corporation for the benefit of its stockholders.”). My sense is that these scholars would also agree that there are some limits on this type of discretion, e.g., that there would be a breach of fiduciary duty if a socialist CEO put the interests of workers and the community before stockholders, such that dividends would only be paid if workers first got raises equal to twice the rate of inflation and the corporation gave charitable donations equal to $10 \%$ of profits, and the board backed the scheme not to advance long-term stockholder welfare, but because the board believed these interests came first and were ends in themselves.

${ }^{281}$ For example, a corporate law scholar I admire very much wrote a provocative article shortly before his death, dealing with the implications of the Citizens United case. One of Professor 
the employees of the corporation? Or its customers? Or the communities in which it operates? Or its creditors?

Within the limits of corporate law itself, the tradition, at least in Delaware, has been that directors must make the best interests of stockholders their end, within the bounds of law. ${ }^{282}$ This is not to say that other constituencies, such as employees or society as a whole, cannot be considered, but they are only to be considered as means to the end of stockholder welfare.

When, however, the federal courts conclude that corporate funds and corporate policies can be directed to advancing religious objectives or political objectives unrelated to stockholder profit, the arguments of those who would have corporate law itself operate on a basis where stockholder welfare is the only legitimate end are much weaker. ${ }^{283}$ If the Supreme Court believes that corporate managers have the ability to use their control

Ribstein's fears was that if Citizens United were rationalized on the ground that the corporation was a vehicle for the expressive rights of its stockholders, then it justified intrusive governmental regulation requiring any political spending to be subject to stockholder approval. Ribstein, supra note 263, at 1022. In making that argument, Professor Ribstein noted that there was the "question of why shareholders' interests should weigh more heavily than those of other stakeholders." Id. at 1038. In that regard, he echoed the view of the majority in Hobby Lobby, which read corporate law as allowing for-profit corporations to pursue many ends other than profits, and as not requiring stockholders to come first. Thus, Professor Ribstein asked why constituencies such as creditors should not have a say over corporate speech and "[p]erhaps most importantly, it is not clear why shareholders' expressive interests should take precedence over those of employees ....” Id. Admittedly, Professor Ribstein assumed that employees would identify far more closely with their employer's speech than stockholders themselves, which I believe to be debatable. For now, however, it is interesting that if the corporation is conceived of as having many stakeholders, the link in Hobby Lobby between the corporate entity and equity owners is in some tension with the majority's own argument that corporations can have nonprofit motivations as ends. If that is the case, why look through the entity to only one constituency?

${ }^{282}$ See supra note 270.

${ }^{283}$ See generally Strine \& Walter, supra note 254. 
of the corporation for religious and ideological purposes, then corporate law itself may have to change. Although pass-through voting to equity owners is awkward and inefficient, there is a strong argument that, for example, 401(k) investors should control how their capital is used for purposes unrelated to stockholder welfare, including the ability to veto any religious or political practices they disagree with. ${ }^{284}$ As it stands now, though, corporate law has no rational way to reconcile the diverse religious, political and social beliefs of such investors and to respond to management perspectives on such issues. $^{285}$

${ }^{284}$ The problem of "separation of ownership from ownership" creates additional complexity in this context. Most stock is now owned by intermediary corporate entities, including mutual and pension funds, rather than individual investors themselves. See, e.g., Marshall E. Blume \& Donald B. Keim, Institutional Investors and Stock Market Liquidity: Trends and Relationships 4 (Aug. 21, 2012), available at http://www.wharton.upenn.edu/jacobslevycenter/files/14.12.Keim.pdf (finding that in 2010, institutional investors held $67 \%$ of equities, compared with $5 \%$ in 1945). Because individual stockholders often have little say in how those funds are directed, it is difficult to discern how they would be able to direct policy or express religious beliefs through two layers of the corporate form. "It is equally difficult to imagine how the plan fiduciaries would come up with a responsible method by which to develop monitoring guidelines about political involvement, given that their plan beneficiaries presumably have diverse views about the range of issues that factor into actual voting by actual humans affected on the many dimensions actual humans are by public policy.” Strine \& Walter, supra note 254, at 48; see also Leo E. Strine, Jr., Toward Common Sense and Common Ground? Reflections on the Shared Interests of Managers and Labor in a More Rational System of Corporate Governance, 33 J. CORP. L. 1, 6-7 (2007). ${ }^{285}$ See Strine \& Walter, supra note 254 at 37-40 ("[S]tockholders have diverse moral and political beliefs and ... their decision to invest in the stock of a for-profit corporation does not constitute any consent to having the corporate managers use corporate funds for political or social purposes.”); see also Roberta Romano, Metapolitics and Corporate Law Reform, 36 STAN. L. REv. 923, 961 (1984) (pursuing goals other than profit maximization is "especially disturbing because profit maximization is the only goal for which we can at least theoretically posit shareholder unanimity”); Henry N. Butler \& Fred S. McChesney, Why They Give at the Office: Shareholder Welfare and Corporate Philanthropy in the Contractual Theory of the Corporation, 84 CORNELL L. REV. 1195, 1223-24 (1999) ("[S]hareholders may have very different views on what is good for society."); id. at 1225 ("Corporate managers have enough trouble meeting the challenges of maximizing shareholder value without diverting their attention to saving the world.”). 
Finally, and of critical importance, because Citizens United enables the corporation to inhibit the ability of government to regulate corporate externalities and expand the social safety net, the argument that internal corporate law constraints are not needed is weakened. ${ }^{286}$ Hobby Lobby's elevation of the interests of corporate managers over those of secular society has a similar effect.

\section{Conclusion}

One of the other critical implications of Hobby Lobby is that it generates incentives for courts to conduct a more searching examination of the sincerity of a litigant's religious beliefs. Under the case law pre-dating Hobby Lobby, the Supreme Court and other courts generally assumed the genuineness of the objector's religious beliefs as a sign of respect. But the court would then go on to explain that the litigant's beliefs had to give way to laws of general applicability that were not targeted at favoring or harming any particular religion. In this way, the prior cases drew on the wisdom of Jesus himself, who famously said, "Render unto Caesar the things that are Caesar's, and

${ }^{286}$ See David G. Yosifon, The Law of Corporate Purpose (Santa Clara Univ. Legal Studies Research Paper No. 14-12, May 2013), http://ssrn.com/abstract=2154031 (“As long as Citizens United is good constitutional law, shareholder primacy is bad corporate theory .... Instead, we must have fundamental reform of corporate governance law which requires directors to actively attend to the interests of multiple stakeholders at the level of firm governance, openly, honestly, and in good faith."); Strine \& Walter, supra note 254, at 63 (“Under conservative corporate theory, the only legitimate reason for a for-profit corporation to make political expenditures will be to elect or defeat candidates based on their support for policies that the corporation believes will produce the most profits. Almost by definition, this will increase the danger of externality risk, because corporate expenditures will be made with the singular objective of stockholder profit in mind, and therefore will be likely to favor policies that leave the corporation with the profits from their operations, while shifting the costs of those operations (including of excessive risk taking or safety short cuts) to others.”). 
unto God the things that are God's.”287 The courts in these cases honored the objecting person's profession of faith, but maintained that any objection was outweighed by the need to ensure that workers received the right to economic autonomy and personal dignity that our duly-elected lawmakers have determined came with a job. If the number of religious-based objections proliferate in the wake of Hobby Lobby, the government or the employees whose interests they represent - may put more pressure on courts to examine these beliefs at the first stage of the RFRA analysis. ${ }^{288}$

The pre-Hobby Lobby cases were consistent with the principle that we, as members of a secular society, must pay taxes or perform other duties for national ends regardless of our individual objections to policy choices. Our taxes fund nuclear missiles, drones, hog and cattle farms, and many other purposes proscribed by some religious or moral creed. The same principle held true for employment: at least since the passage of the Fair Labor Standards Act, employees have been able to spend their wages in ways that their employers would doubtless find religiously or morally objectionable. When an employer simply renders unto Caesar the minimum required under our secular system of laws, it is the worker who chooses what to do with the fruits of her labor, not the employer. But Hobby Lobby disrupts this balance. By assuming that the employer's conscience is burdened by the worker's use of benefits and wages, the myriad individual choices made by workers are subjected to employer objections under RFRA. By further assuming that the government (i.e., other taxpayers) can always pay to make up the

${ }^{287}$ Mark 12:17.

288 These determinations of sincerity would of course be complicated by the question of whose religious beliefs are sincere, as noted in the discussion of corporate law in section $\mathrm{D}$, supra. 
difference, no mandate can ever be the "least restrictive means" of ensuring that the minimum guarantees set by society are met. Thus any religious objection could prevail, not just objections to the four contraceptive methods at issue in the case.

A job is not a hobby. It is a necessity for most of us. In this country, through an accident of history and tax law, it is also the most likely pathway to good healthcare. Starting with Social Security in the 1930s, acting through our elected representatives, we have determined that there are certain minimum essential benefits that must accompany employment. Giving employers the right to chip away at these minimum essential benefits owed to their employees in the name of religion risks repeating the mistakes of our paternalistic past and infringing on worker freedom. The Hobby Lobby majority would have done well to heed the words of Justice Scalia, writing in Smith:

Precisely because "we are a cosmopolitan nation made up of people of almost every conceivable religious preference," and precisely because we value and protect that religious divergence, we cannot afford the luxury of deeming presumptively invalid, as applied to the religious objector, every regulation of conduct that does not protect an interest of the highest order. [That] would open the prospect of constitutionally required religious exemptions from civic obligations of almost every conceivable kind ranging from compulsory military service, to the payment of taxes; to health and safety regulation such as manslaughter and child neglect laws, compulsory vaccination laws, drug laws, and traffic law; to social welfare legislation such as minimum wage laws, child labor laws, animal cruelty laws, environmental protection laws, and laws providing for equality of opportunity for the races. The First Amendment's protection of religious liberty does not require this. ${ }^{289}$

Nor does RFRA.

${ }^{289}$ Emp't Div. v. Smith, 494 U. S. 872, 888-89 (1990) (internal citations omitted). 